\title{
Assessment of End of Life Disposal, Tritium Recovery and Purification Strategies for Radioluminescent Lights
}
G. A. Jensen
R. F. Hazelton
R. E. Ellefson
H. S. Carden

October 1991

Prepared for the U.S. Department of Energy under Contract DE-AC06-76RLO 1830

Pacific Northwest Laboratory Operated for the U.S. Department of Energy by Battelle Memorial Institute 


\title{
DISCLAIMER
}

This report was prepared as an account of work sponsored by an agency of the United States Government. Neither the United States Government nor any agency thereof, nor Battelle Memorial Institute, nor any of their employees, makes any warranty, expressed or implied, or assumes any legal liability or responsibility for the accuracy, completeness, or usefulness of any information, apparatus, product, or process disclosed, or represents that its use would not infringe privately owned rights. Reference herein to any specific commercial product, process, or service by trade name, trademark, manufacturer, or otherwise does not necessarily constitute or imply its endorsement, recommendation, or favoring by the United States Government or any agency thereof, or Battelie Memorial Institute. The views and opinions of authors expressed herein do not necessarily state or reflect those of the United States Government or any agency thereof.

\author{
PACIFIC NORTHWEST LABORATORY \\ operated by \\ BATTELLE MEMORIAL INSTITUTE \\ for the \\ UNITED STATES DEPARTMENT OF ENERGY \\ under Contract DE-ACO6-76RLO 1830
}

Printed in the United States of America

Available to DOE and DOE contractors from the

Office of Scientific and Technical Information, P.O. Box 62, Oak Ridge, TN 37\$31; prices available from (615) 576-8401. FTS 626-8401.

Available to the public from the National Technical Information Service,

U.S. Department of Commerce, 5285 Port Royal Rd., Springfield, VA 22161. 
ASSESSMENT OF END OF LIFE DISPOSAL, TRITIUM RECOVERY AND PURIFICATION STRATEGIES FOR RADIOLUMINESCENT LIGHTS
G. A. Jensen
R. F. Hazelton
R. E. Ellefson (a)
H. S. Carden

October 1991

Prepared for the U.S. Department of Energy under Contract DE-AC06-76RLO 1830

Pacific Northwest Laboratory

Richland, Washington 99352

(a) EG\&G Mound Applied Technologies.

(b) Quil1 Associates, Dayton, Ohio. 


\section{SUMMARY}

Tritium-powered radioluminescent ( $R L$ ) lighting has been commercially available for over twenty-five years. In existing commercial technology, glass tubes coated internally with a phosphor are filled with tritium and sealed, and the tubes are mounted into plastic or other housing materials. The initial quantities of tritium contained in these devices have ranged from a few millicuries in avionic instruments and other military devices to about $30 \mathrm{C} i$ in commercially available exit signs. Normally, at the end of their useful lives, the devices are to be returned to the manufacturer for disposal.

Work on advanced glass tube technology for the U.S. Department of Energy (DOE) has produced sealed sources or tubes containing up to $166 \mathrm{Ci}$ of tritium each, giving $996 \mathrm{Ci}$ in a six-tube RL runway light. Advanced solid state technologies are also under investigation. The DOE expects to transfer technologies that are developed to the military and public sectors.

Concurrently with pitting the technology to use, a methodology is needed to ensure the collection, safe storage, and final disposal of the RL lights at the end of their useful lives. Consequently, an understanding of disposal practices for currently used RL devices is needed as a basis for developing methodologies to safely handle and dispose of devices using advanced technologies. Issues related to the safe handling and return of the devices, recovery of tritium from the aged-out devices for recycle, and disposal of wastes resulting from the recovery process have been topics of discussion at meetings of DOE's RL Lights Technical Working Group (TWG). The TWG discussions resulted in the work presented here.

The objective of this joint assessment by the Pacific Northwest Laboratory and EG\&G Mound Applied Technologies is to identify and examine options for disposal of aged-out RL lights based on current technology, and for the possible recovery and purification of tritium from the lights and disposal of the resulting contaminated remnants. The focus of the assessment is on the waste disposal and tritium recycling issues that will evolve with use of the advanced RL lighting technology and that are relevant to industrial suppliers and to civilian, military, and other government users. The scope of 
work also includes identification of the potential financial benefits and risks of recycle versus direct disposal.

To accomplish this task, manufacturers, military users, disposal site operators, and others were contacted concerning current usage patterns and practices for recovery and disposal of RL devices at the end of their useful lives. Available processes for dismantling glass tube RL devices and recycling the tritium were also evaluated and the costs for recovery of the tritium were compared with direct disposal options. The result of this comparison demonstrated that the tritium in devices containing more than $10 \mathrm{Ci}$ may be recovered profitably, and devices containing less than $10 \mathrm{Ci}$ should be disposed of since costs for recovery can exceed disposal costs. This is because disposal of RL devices containing $10 \mathrm{Ci}$ of tritium (value $\$ 3.00 / \mathrm{C}$ ) will cost -\$64 per device. The net cost for tritium recovery and sale, i.e., total recovery cost (including disposal of shards, etc.)--tritium value, is $-\$ 63$ per device; approximately equal. Since disposal of shards, etc. is a minor factor ( $-5 \%$ of the recovery costs), the major factors affecting the break even point will be increases in disposal costs (volume cost) or increases in the value of tritium. For example, if the cost of tritium is increased to $\$ 4.00 / \mathrm{C} i$ the net recovery cost drops to $-\$ 54 /$ device; $-\$ 9 /$ device less than the disposal cost. A similar analysis can be applied if disposal costs increase. Recovery of tritium from devices developed for runway lighting and marking the DOE'S RL Lighting program is definitely advantageous because of the large quantities of tritium contained in the RL tubes.

Generally, a waste package of end-of-life RL devices will be disposed by burial as $\mathrm{Class} A$ waste if it contains $40 \mathrm{Ci} / \mathrm{m}^{3}$ or less of tritium or as Class $B$ waste if it contains greater than $40 \mathrm{Ci} / \mathrm{m}^{3}$. Tritium in disposed devices can be as a gas or be bound as a solid; any liquid waste containing tritium would have to be solidified or packaged in absorbents according to 10 CFR 61. Specific requirements for disposal are identified in the regulations and by disposal site requirements. These requirements are subject to change and are not therefore detailed in this report. 


\section{CONTENTS}

SUMMARY

i i i

1.0 INTRODUCTION . . . . . . . . . . . . . . . . . . . 1.1

2.0 USE PATTERNS FOR CURRENT RL DEVICE TECHNOLOGY . . . . . . . . . . 2.1

2.1 TRITIUM SALES TO THE COMMERCIAL SECTOR . . . . . . . . 2.1

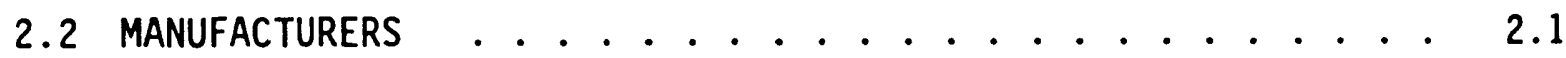

2.3 MILITARY USERS . . . . . . . . . . . . . . . . . 2.4

2.3 .1 U.S. Army ................... 2.4

2.3.2 U.S. Air Force ............... 2.4

2.3 .3 U.S. Navy .................... 2.6

2.4 NATIONAL LABORATORIES . . . . . . . . . . . . . 2.6

2.4.1 Oak Ridge National Laboratory . . . . . . . . . 2.6

2.4.2 Pacific Northwest Laboratory . . . . . . . . . . 2.7

3.0 REGULATORY ISSUES AND DISPOSAL PRACTICES FOR RL DEVICES . . . . . 3.1

\begin{tabular}{l}
4.0 ALTERNATIVE TO DISPOSAL: EOL TRITIUM RECOVERY FROM \\
RL DEVICES... \\
\hline
\end{tabular}

4.1 RECOVERY IN ENGLAND . . . . . . . . . . . . . . . . . . . 4.1

4.2 CONCEPTUALIZED TRITIUM RECOVERY PROCESS . . . . . . . . . 4.1

4.2.1 Categories of RL Tubes ............. . 4.3

4.2.2 Expected Composition of Gas from RL Tubes . . . . . . 4.4

4.3 TRITIUM RECOVERY PROCESS . . . . . . . . . . . . . . . . 4.4

4.3.1 Gas Release Methods . . . . . . . . . . . . 4.5

4.3.2 Operational Steps in the Recovery of Tritium 4.10

from RL Tubes ............. . 4.10

4.4 COST ANALYSIS FOR TRITIUM RECOVERY . . . . . . . . . . . . . 4.16

4.4.1 Operating Costs ................ 4.16 
4.5 CAPITAL COSTS ................... 4.21

4.6 COMPARISON OF TRITIUM RECOVERY COSTS WITH DIRECT DISPOSAL COSTS................... 4.22

5.0 CONCLUSIONŚ . . . . . . . . . . . . . . . . . . . . 5.1

6.0 REFERENCES .......................... . . . 6.1 


\section{FIGURES}

2.1 RL Lights Lifecycle flow . . . . . . . . . . . . . . 2.2

2.2 RL Light Tube Used in DOE RL Light Program Panels and Superwands from 1983-85................. . . 2.8

2.3 Panel and Superwand Used in DOE's RL Lights Program Before 1985 . . . . . . . . . . . . . . . . . . 2.8

2.4 RL Light Tube Used in DOE RL Light Program Panels or Wands After 1985 . . . . . . . . . . . . . . . . . 2.9

2.5 RL Light Panels and Wands Used in DOE's RL Lights Program After 1985 . . . . . . . . . . . . . . . 2.9

4.1 Oak Ridge Design for a Tritium Recovery System with Manual Tube Crushing Fixture ................ 4.2

4.2 Gas Release, Purification and Tritium Enrichment Facilities ...................... 4.8

4.3 Mound Flow Diagram of Activities for Recovery and Enrichment of Tritium from End-of-Life RL Light Tubes . . . . . . . . 4.12 


\section{TABLES}

2.1 Tritium Sales by ORNL . . . . . . . . . . . . . . . 2.2

2.2 U.S. Army Proculement of RL Devices . . . . . . . . . . . . 2.5

2.3 U.S. Air Force RL Device Disposal . . . . . . . . . . . . 2.5

2.4 PNL RL Lights Inventory (Apri1 1991) . . . . . . . . . . 2.10

4.1 Tritium Gas Composition for Various RL Devices . . . . . . . . 4.5

4.2 Comparison of Total Tritium in RL Devices by Calorimetry and PVT/MS Analysis of Gas Released on Fracture . . . . . . . . . 4.6

4.3 Tritium Content of ORNL 10 in. $x 1 / 2$ in. Tubes ....... 4.7

4.4 Summary of Operations Costs for Tritium Recovery from End-of-Life RL Devices in Various Commercial Products . . . . . . 4.17

4.5 Cost to Recover Tritium from EXIT Signs of $20 \mathrm{Ci}$ or Less . . . 4.17

4.6 Cost to Recover Tritium in Residuals ............ 4.18

4.7 Cost to Pecover Tritium from USAF 6-Tube Panels . . . . . . . 4.18

4.8 Cost to Recover Tritium from ORNL Light Wands . . . . . . . . 4.19

4.3 Disposal Cost for RL Devices . . . . . . . . . . . . 4.24 


\subsection{INTRODUCTION}

Tritium-powered radioluminescent ( $R L$ ) lighting has been commercially available for over twenty-five years for self-powered exit and other signage in buildings and aircraft, and for watches, instruments, and avionic and other devices used for applications requiring self-powered lighting. In existing commercial technology, glass tubes coated internally with a phosphor are filled with tritium and sealed, and the tubes are mounted into plastic or other housing materials for use. The initial quantitif:s of tritium contained in these devices have ranged from a few millicuries in avionic instruments and other military devices to about $30 \mathrm{Ci}$ in commercially available exit signs. All commercially manufactured devices are licensed and sold under the provisions of 10 CFR 30-35 for byproduct materials. At the end of their useful lives, the devices are normally returned to the manufacturer for disposal.

Advanced glass tube technology under development by the $U$. S. Department of Energy (DOE) for the past several years has produced sealed sources or tubes containing up to $166 \mathrm{Ci}$ of tritium each, giving $996 \mathrm{C} i$ in a six-tube $\mathrm{RL}$ runway light. The useful life of these sources is expected to be a minimum of 8 years to perhaps as long as 13 years. Advanced solid-state technologies are also under investigation, but because they are still in early stages of development no predictions can be made concerning their useful lives. A continuing transfer of DOE-developed technology to other agencies and the private sector is expected.

Concurrent with putting the technology to use, a methodology is needed to ensure the collection, safe storage, and final disposal of the RL lights at the end of their useful lives. Consequently, an understanding of practices with currently used RL lighted devices is needed as a basis for developing methodologies for safe handling of devices using the advanced technology. Issues related to the safe handling and return of the devices, tritium recovery of tritium from the aged-out devices for recycle, and disposal of wastes resulting from the recovery process have been topics of discussion at meetings of DOE's RL Lights Technical Working Group (TWG). One result of the TWG discussions is the work presented here. 
The objective of this joint assessment by the Pacific Northwest Laboratory $(P N L)^{(a)}$ and EG\&G Mound Applied Technologies(b) is to identify and examine options for disposing of the aged-out RL lights based on experience with the currently used technology, and for the possible recovery and purification of tritium from the lights and disposal of the resulting contaminated remnants. Although this study on the recovery of RL lights is a unified effort between PNL and Mound, each laboratory had specific assignments in several task areas. PNL addressed 1) the existing inventory of RL devices 2) regulatory factors related to disposal, and 3) disposal costs and options at the end of useful life (EOL), specifically burial without recovery of the tritium. PNL also compared the disposal option with the recovery option to identify a "break even" point where recovery of tritium in larger light units could be justified. Mound addressed two aspects: 1) evaluation of existing tritium recovery technologies with the aim to select or design a preferred method, and 2) a comparison cost evaluations for recovering and purifying the tritium from the several types of light tubes in inventory with a comparison of the projected cost effectiveness of reclamation versus burial. Waste stream quantities are computed for each device type with associated burial costs.

The report also briefly addresses the waste disposal and tritium recycling issues that will evolve with use of the advanced RL lighting technology and that are of relevance to industrial suppliers and to civilian, military, and other government users. The scope of work also includes identification of the potential financial benefits and risks of recycle versus direct disposal.

The following sections of this report cover the use patterns for current technology RL lights, regulatory issues, disposal practices, tritium recovery at the end of RL light service, comparison of tritium recovery costs with those of direct disposal, and the conclusions.

(a) Operated for the U.S. Department of Energy by Battelle Memorial Institute under Contract DE-AC06-76RLO 1830.

(b) Operated for the U.S. Department of Energy by EG\&G Mound Applied Technologies under Contract DE-AC04-88-DP43495 


\subsection{USE PATTERNS FOR CURRENT RL DEYICE TECHNOLOGY}

Volume of tritium sales, manufacturer production, and use patterns are discussed in this section. Much of the information discussed was obtained from manufacturers and is therefore consolidated to ensure confidentiality for the information sources. Specifics provided without restriction are identified. Specific civilian users of RL lights were not contacted since they are numerous and their identities and locations are proprietary.

\subsection{TRITIUM SALES TO THE COMMERCIAL SECTOR}

Based on tritium sales, from 10 to 20 million curies of tritium has been packaged into RL signs over the 25 years of the industry's existence. One of the tritium licensing requirements for device manufacturers is a provision for accepting signs back from the user of commercial products (primarily EXIT signs) at end of life (EOL). This is to ensure proper disposal or recovery of the remaining tritium in the device. Although it would be advantageous to know the inventory of RL devices that have been returned to the manufacturers, these data are not readily available since they are regarded as sensitive and/or proprietary information by the light fabricators. As reported, the annual tritium sales by Oak Ridge National Laboratory (ORNL) to commercial users from FY 1980 through FY 1989 are listed in Table 2.1.

The total for the ten years of tritium sales is about 14.4 million $\mathrm{Ci}$, undecayed, an average of 1.44 million $\mathrm{Ci}$ per year for the ten years. The decrease in sales in FY 89 was attributed to the price increase by ORNL isotope sales that year.

The flow of tritium from production through use to ultimate disposal is shown schematically in Figure 2.1 .

\subsection{MANUFACTURERS}

Several U. S. manufacturers of tritium-powered RL lighting devices were contacted to obtain information on the types and number of devices they manufacturer, the initial tritium $\mathrm{Ci}$ contents, expected useful lives, materials of construction, numbers or percentages returned for disposal, disposal or 
TABLE 2.1. Tritium Sales by $\operatorname{ORNL}^{(a)}$

\begin{tabular}{lrrrr} 
FY & Tritium, Ci & FY & Tritium, Ci \\
\cline { 5 - 5 } & & & \\
80 & 955,233 & 85 & $1,400,087$ \\
81 & 918,215 & 86 & $1,737,559$ \\
82 & $1,203,543$ & 87 & $1,777,360$ \\
83 & $1,864,664$ & 88 & $2,376,728$ \\
84 & $1,470,363$ & 89 & Ca 700,000
\end{tabular}

(a) Telephone Conversation with Carl W. Haff ORNL, March 26, 1990.

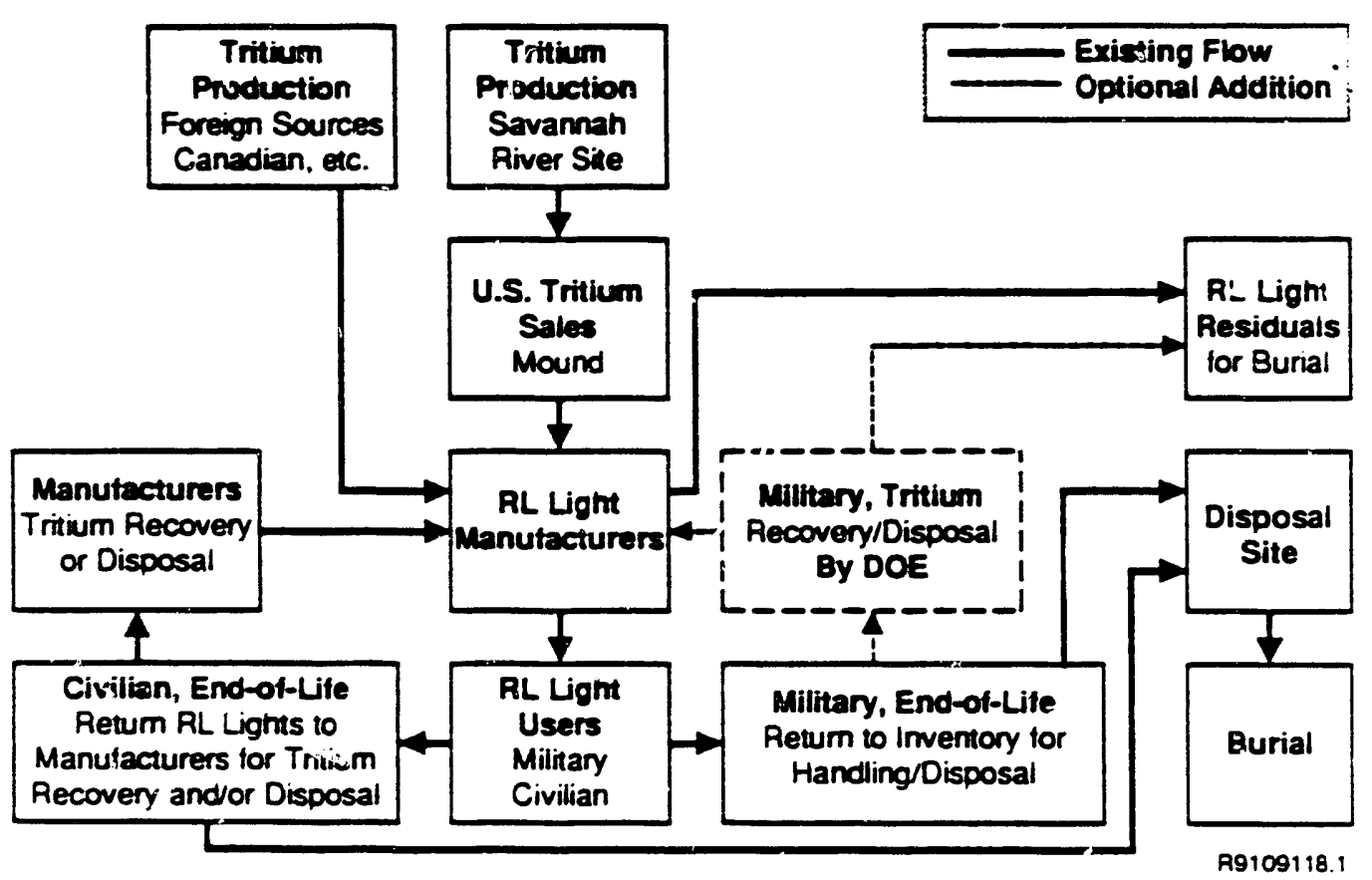

FIGURE 2.1. RL Lights Lifecycle Flow

tritium recovery and recycle practices for aged-out devices, and associated information. Much of the information provided is proprietary, however the essence of the information obtained is summarized in the following.

The primary devices in number (well over 90\%) and in $\mathrm{Ci}$ used that are manufactured are self-luminous exit and other emergency signs: about 90,000 signs containing roughly 1.3 million $\mathrm{C} i$ have been made annually on an average 
for about the past five years. This amount of tritium use in exit signs and other RL light devices is approximately equal to that for tritium reported as sold to the commercial sector. Production is expected to increase at a rate of 8 to $10 \%$ per year. Each EXIT sign contains from 5 to $20 \mathrm{Ci}$ of tritium in the gaseous state, and depending on the $C i$ content, brightness, particular design, and manufacturer, has an expected useful life of about 7 to 12, and in some cases 20 years. The shorter life is for signs of lower $\mathrm{Ci}$ content. The average useful life is about 12 years, or one tritium half-life. About half of the EXIT signs are less than 5 years old.

Production of millicurie devices is apparently a relatively small fraction of the business in number of devices sold as well as in their tritium $\mathrm{Ci}$ content; specifics on tritium usage in these devices were not obtained. A few thousand high-Ci (i.e. $>84 \mathrm{Ci}$ per tube) lig̣ting devices have been made commercially for DOE's RL Lights Program for use for airfield edge lighting, but none have yet reached the end of their service life.

Commercial exit signs and those constructed for the DOE use borosilicate glass tubes (the primary tritium containment; tubes internally coated with a phosphor), soda lime glass, butyrates, ABS plastics, polystyrene, polycarbonates, acrylics, aluminum, steel, vinyl, silicones, and foams in their construction.

Most aged-out EXIT signs produced by a manufacturer were reported as being returned to that manufacturer. Some manufacturers have gone out of business; consequently, signs made by them have had to be sent directly to a disposal site by the user. The average age of EXIT signs that have been removed and stored for disposal is about 10 years. The duration of storage of the waste at the manufacturer's site before ultimate disposal ranges from 0.25 to 2 years depending on the manufacturer. Land burial of EOL EXIT signs is performed at one of the three U.S. radioactive waste burial sites. Tritium recovery is performed overseas. 


\subsection{MILITARY USERS}

Military users were also contacted to learn of their radioluminescent light uses and their disposal practices. The information acquired by telephone conversations and letters follows:

\subsubsection{U.S. Army}

The U.S. Army provided its best approximation of procurements since 1977. The Army uses tritium-powered liginting for illumination of rifle sights and fire control devices on howitzers and mortars for night firing. A muzzle reference sensor, which is used on the end of tank gun barrels for collimation, also uses tritium-powered lighting for illumination. The containment for tritium gas is borosilicate glass. The largest individual source is $10 \mathrm{Ci}$, but many sources are below $1 \mathrm{Ci}$. Data are given below in Table 2.2; activities are for initial curies with no decay factored in. The expected useful life for each type of device is 6 to 10 years. The Army predicted that its future annual acquisition would be about 7,500 devices having 33,000 $\mathrm{Ci}$, which would average about $4.4 \mathrm{Ci}$ per device. It has disposed of about $25 \%$ of the devices it has obtained since 1977. In 1990, disposal amounted to 12,600 devices containing about $10,200 \mathrm{Ci}$. The average service age of devices stored for disposal is 6 years, and storage time before disposal averages 6 months to 1 year. The aged-out devices are disposed at the Barnwell, SC, commercial burial site. No tritium is recovered.

\subsubsection{U.S. Air Force.}

The Air Force office contacted deals only with condemned items containing radioactive material for disposal, and in this function has no access to inventory management records from which to estimate numbers of devices and $\mathrm{C} i$ quantities in the supply inventory. The devices the office has handled fall into several broad categories with the most common being generally licensed, tritium-powered RL EXIT signs. Information provided on devices it has or has had for disposal is listed in Table 2.3 
TABLE 2.2. U.S. Army Procurement of RL Devices(a)

\begin{tabular}{|c|c|c|c|c|c|c|}
\hline \multicolumn{2}{|c|}{ Activity Range } & No. of Sources & \multicolumn{2}{|c|}{ Total Activity } & \multicolumn{2}{|c|}{ Avg $\mathrm{Ci} /$ Source } \\
\hline $\begin{array}{r}0-100 \\
0.1-1 \\
0-10\end{array}$ & $\begin{array}{l}\mathrm{mC} i \\
\mathrm{Ci} \\
\mathrm{Ci}\end{array}$ & $\begin{array}{r}27,189 \\
9,239 \\
72,849 \\
109,277\end{array}$ & $\begin{array}{r}2,041 \\
5,252 \\
401,027 \\
408,320\end{array}$ & $\begin{array}{l}\mathrm{Ci} \\
\mathrm{Ci} \\
\mathrm{Ci} \\
\mathrm{Ci}\end{array}$ & $\begin{array}{r}75 \\
568 \\
5.5\end{array}$ & $\begin{array}{l}\mathrm{mCi} \\
\mathrm{mCi} \\
\mathrm{Ci}\end{array}$ \\
\hline
\end{tabular}

Age Grouping

\begin{tabular}{|c|c|c|}
\hline Age Years & No. of Devices & $\mathrm{Ci}$ \\
\hline $\begin{array}{l}<5 \\
5-10 \\
>10\end{array}$ & $\begin{array}{r}47,547 \\
56,266 \\
5,464 \\
109,277\end{array}$ & $\begin{array}{r}183,999 \\
198,933 \\
25,388 \\
408,320\end{array}$ \\
\hline
\end{tabular}

(a) Letter, February 1991: David P. Skogmay, Chief, Systems, Chemical, Radiation Division, Hq. U.S. Army Armament, Munitions \& Chemical Command to Richard F. Hazelton, PNL.

TABLE 2.3. U.S. Air Force RL Device Disposal ${ }^{(a)}$

\begin{tabular}{|c|c|c|c|c|c|c|}
\hline \multicolumn{2}{|c|}{$\begin{array}{l}\text { Activity } \\
\text { Range } \\
\end{array}$} & \multicolumn{2}{|c|}{$\begin{array}{l}\text { Total } \\
\text { Activity }\end{array}$} & \multicolumn{2}{|c|}{$\begin{array}{l}\text { Stored } \\
\text { Activity }\end{array}$} & Type of Device \\
\hline $\begin{array}{r}0.1-1 \\
1-10\end{array}$ & $\begin{array}{l}\mathrm{Ci} \\
\mathrm{Ci}\end{array}$ & $\begin{array}{l}11.5 \\
1190\end{array}$ & $\begin{array}{l}\mathrm{Ci} \\
\mathrm{Ci}\end{array}$ & $\begin{array}{r}0 \\
100\end{array}$ & $\begin{array}{l}\mathrm{Ci} \\
\mathrm{Ci}\end{array}$ & $\begin{array}{l}\text { Electron tubes, EC detector } \\
\text { Primarily EXIT signs; } \\
\text { also detector cells }\end{array}$ \\
\hline $\begin{array}{l}10-25 \\
25-50\end{array}$ & $\begin{array}{l}\mathrm{Ci} \\
\mathrm{Ci}\end{array}$ & $\begin{array}{r}7118 \\
84\end{array}$ & $\begin{array}{l}\mathrm{Ci} \\
\mathrm{Ci}\end{array}$ & $\begin{array}{r}2000 \\
0\end{array}$ & $\begin{array}{l}\mathrm{Ci} \\
\mathrm{Ci}\end{array}$ & $\begin{array}{l}\text { Primarily EXIT signs } \\
\text { Safety sign, calibrator }\end{array}$ \\
\hline
\end{tabular}

(a) Letter, April 1991: David C. Adams, Major USAF to Richard F. Hazelton, PNL.

Half of the devices in the 1-10 Ci range are 5 to 10 years old; half, greater than 10 years. All the other devices were presumed to be in the 5 to 10 year age grouping. Tritium was usually in the gaseous state in the Air Force devices, but some tritium was used in the solid state; the electron tubes and the EC detector in the 0.1-1.0 Ci range as well as detector cells in 
the 1 to $10 \mathrm{Ci}$ range used the solid state. Construction materials for the lower $\mathrm{Ci}$ range were glass (not borosilicate) and aluminum, and for the higher range, aluminum, other metals, and plastics other than polycarbonates or polyacrylates. Storage before disposal is 6 to 12 months. The waste is disposed by burial.

\section{3 .3 U.S. Navy}

The U.S. Navy reported ${ }^{(a)}$ that they do not have many RL light sources, and that the only RL light sources they have had were EXIT signs having up to $20 \mathrm{Ci}$ of tritium. These generaliy have been returned to the manufacturer except for 20 to 30 signs now in storage. The Marine Corps uses fire control devices, but these are obtained through the U.S. Army, and consequently the Marines' devices fall under the Army's accounting. The Navy's radioactive waste disposal, as well as that of the Air Force, is now being turned over to the U.S. Army; this centralization of waste handling by the military is at Rock Island, Illinois.

\subsection{NATIONAL LABORATORIES}

Oak Ridge National Laboratory (ORNL) and the Pacific Northwest Laboratory (PNL) have been major participants in DOE's RL Lights Program since the late 1970s. A number of RL devices were manufactured by ORNL or developed under ORNL contract for the program. Many of these devices were transferred to PNL for subsequent testing, evaluation, and demonstration by potential users. Residual inventories are presented here.

\subsubsection{Oak Ridge National Laboratory}

ORNL reports ${ }^{(b)}$ that they have approximately $100,000 \mathrm{Ci}$ of tritium in miscellaneous RL devices in their inventory. Most of these devices are

(a) Telephone conversations, 1990-91: Richard Loman, U.S. Navy, Yorktown, VA and Richard F. Hazelton, PNL.

(b) Telephone conversation, September 6, 1991: Karl Haff, ORNL and George Jensen, PNL. 
panels, superwands, tubes and other tritium sources residual to the development work under way prior to 1988. Decisions related to the ultimate disposition of these devices are pending.

\subsubsection{Pacific Northwest Laboratory (PNL)}

Since about 1982, PNL has had under its control a number of relatively large, prototypic RL lights made at ORNL or made commercially for remote airfield runway applications. Two sealed glass tube designs have been used in the construction of these lights. In panels and superwands built in 1983-84, the tube cross section is crescent shaped, 9.5 in. lighted surface length, $0.880 \mathrm{in}$. wide and between 0.490 and $0.520 \mathrm{in}$. thick (Figure 2.2). These tubes contained $50 \mathrm{Ci}$ each and were used in superwand or panel configurations (Figure 2.3). The superwands are $2.75 \mathrm{in}$. in diameter and $12.375 \mathrm{in}$. long and contained two or three crescent shaped tubes. The panels are $12.75 \mathrm{in}$. square and $2.68 \mathrm{in.}$ ( $211 / 16$ in.) thick. The crescent shaped tubes were shock mounted and the designs met or exceeded the ANSI 540 Standard for RL devices.

After 1985, light panels and wands were built for the program for testing as runway edge lighting by Safety Light Corporation, Bloomsburg, Pennsylvania (Tompkins et al. 1990). These wands and panels contained tritium sealed in annular borosilicate glass tubes approximately 1 in. outside diameter (OD), are either approximately 5 or $10 \mathrm{in.}$ long, and contain 83 or $166 \mathrm{Ci}$, respectively (Figure 2.4). The 5 -in. tubes are housed in 1.5-in.-OD polycarbonate tubes for wand configurations. A single 5 -in. tube (83 $\mathrm{C} i$ ) is shock mounted in a polycarbonate tube for a wand $8.625 \mathrm{in}$. long or two 5 -in. tubes (166 $\mathrm{Ci}$ ) are shock mounted inside a polycarbonate tube to produce a wand $15.125 \mathrm{in.}$ long. The 10-in. tubes are used in panels, six tubes/panel, mounted three per side, and each panel contains $996 \mathrm{Ci}$. The wands have been tested to meet the ANSI 540 standard for radioluminescent devices and the panels were qualified to meet the DOT 7A Transportation Requirements (Tompkins et a1. 1990). These devices are shown in Figure 2.5. The PNL inventory of RL lights at Hanford and in Alaska is found in Table 2.4. 


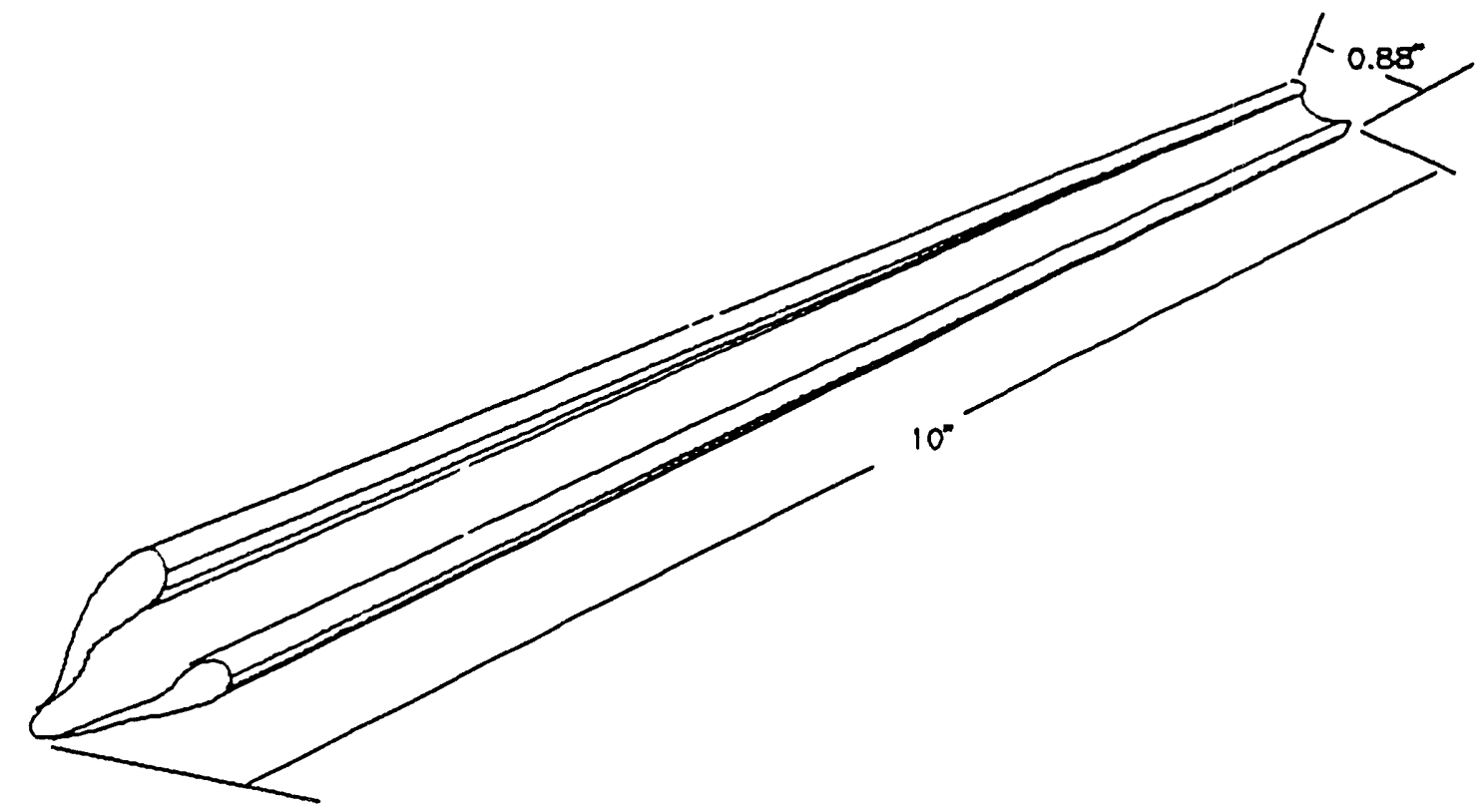

FIGURE 2.2. RL Light Tube Used in DOE RL Light Program Panels and Superwands from 1983-85
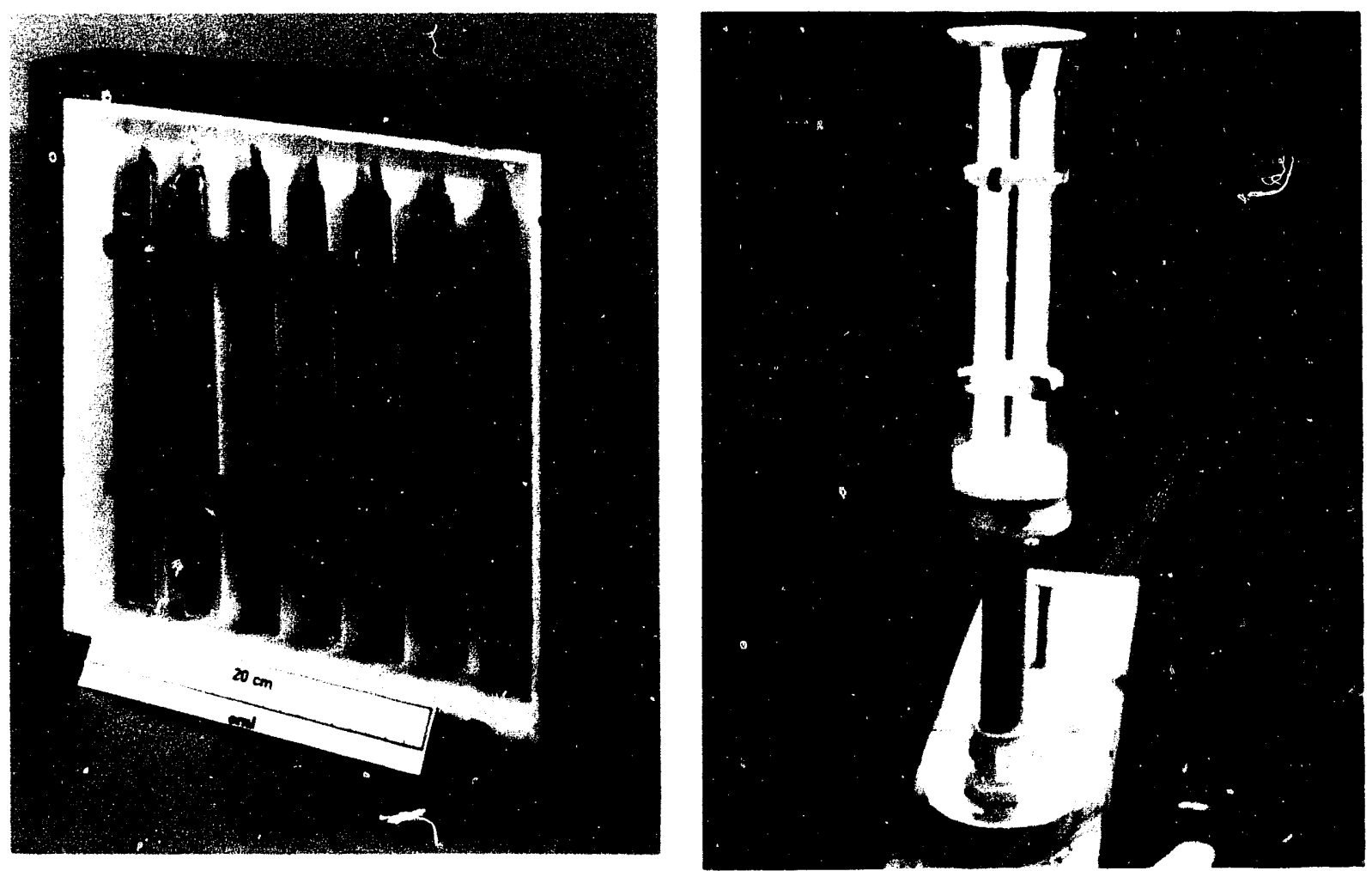

FIGURE 2.3. Panel (1eft) and Superwand (right) Used in DOE's RL Lights Program Before 1985 


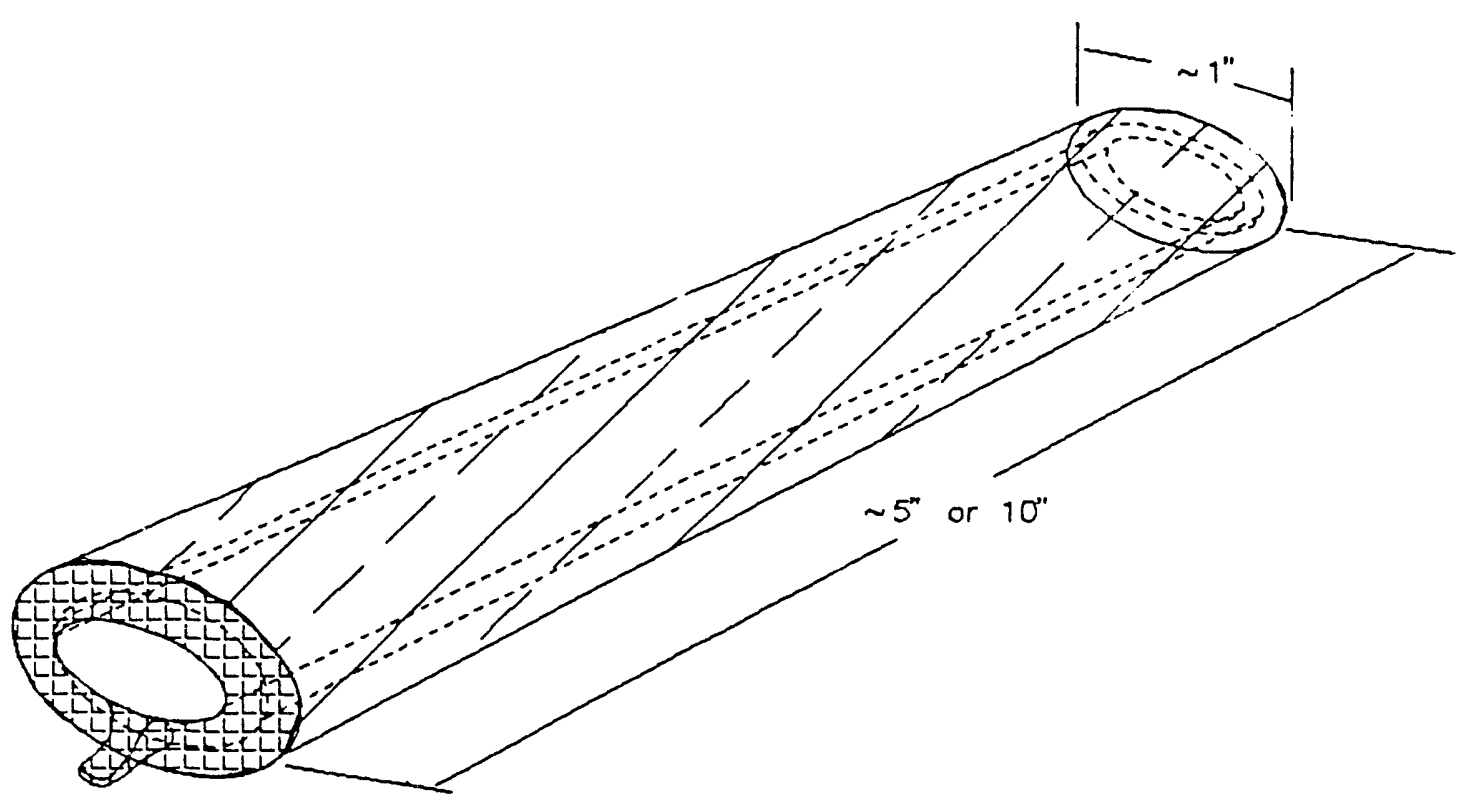

FIGURE 2.4. RL Light Tube Used in DOE RL Light Program Panels or Wands After 1985

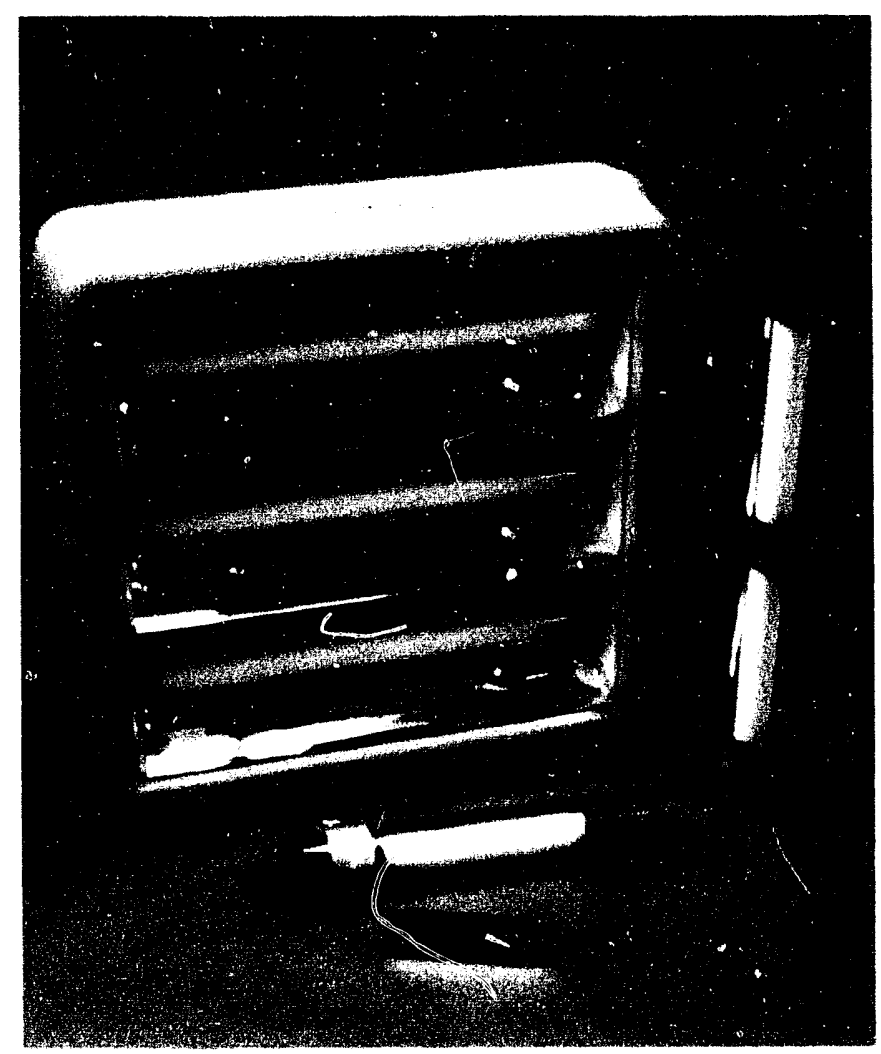

FIGURE 2.5. RL Light Panels and Wands Used in DOE's RL Lights Program After 1985 


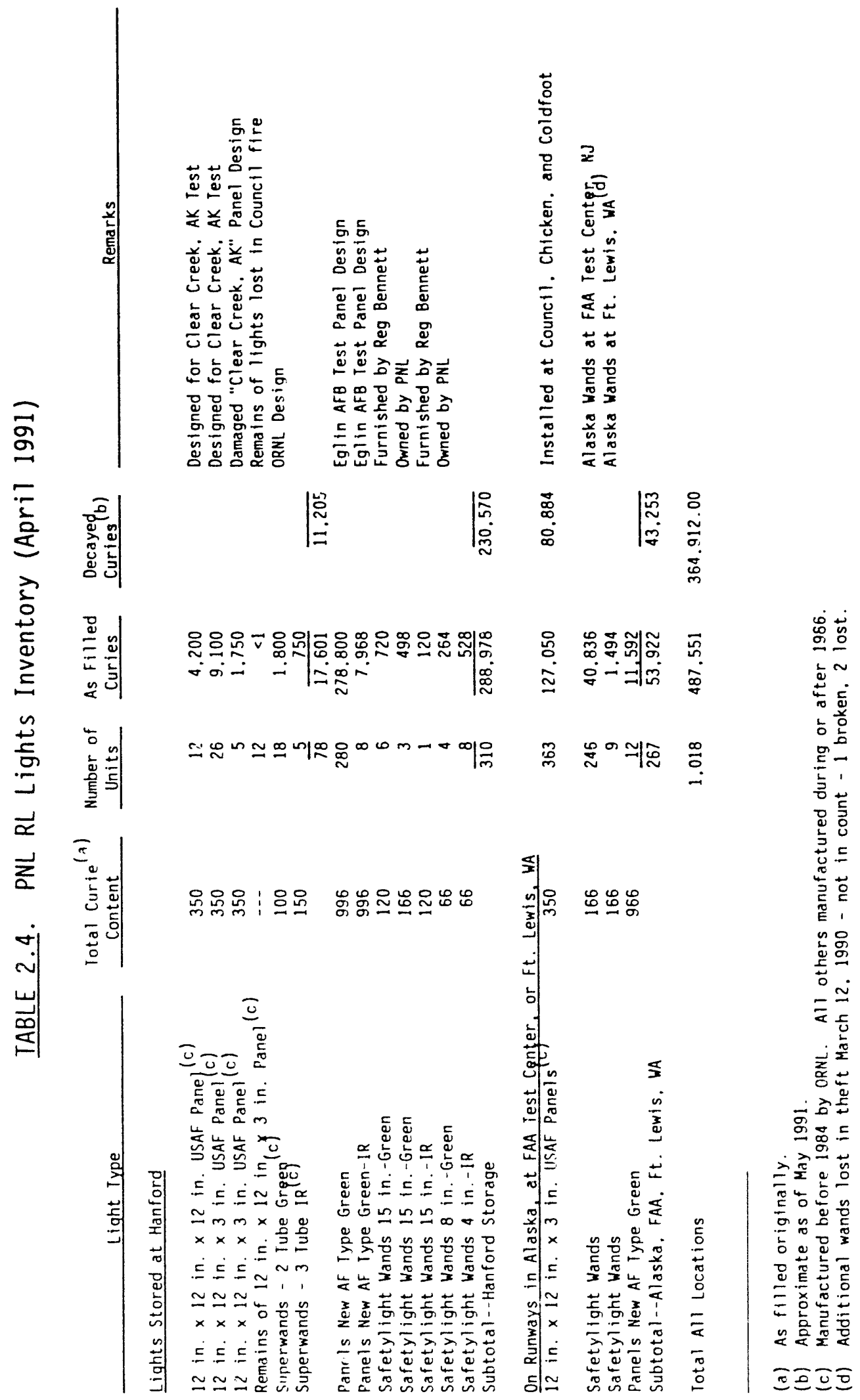




\subsection{REGULATORY ISSUES AND DISPOSAL PRACTICES FOR RL DEVICES}

Aged-out RL devices that are to be disposed by land burial are shipped to either the Barnwell radioactive waste disposal site, operated by Chem Nuclear Systems, Inc., in South Carolina, or to the Richland disposal site in Washington or the Beatty disposal site in Nevada, the latter two radioactive waste disposal sites being operated by U.S. Ecology, Inc. Shipment of the waste must conform to 49 CFR 173 controlled by the U.S. Department of Transportation (DOT) and to 10 CFR 71 controlled by the U.S. Nuclear Regulatory Commission (NRC); disposal, to 10 CFR 61 controlled by the NRC.

49 CFR 173 Subpart I sets forth requirements for transportation of radioactive materials by carriers and shippers that are similar to requirements given in 10 CFR 71 . These two regulations describe the packaging that must be used to contain the waste during shipment and the tests that must be performed for qualifying the packages. The quantity of tritium to be shipped in a single container determines whether a Type A or a Type B shipping package, defined in the codes, would be used. The U.S. DOT limits the activity in a Type A package for shipment to $1000 \mathrm{Ci}$ of gaseous tritium. If containers having greater than $1000 \mathrm{Ci}$ of tritium gas were to be shipped, a certified Type B overpack or cask must be used; however, more than one container can be in a shipment. This latter type of shipment requires approvals, needs certified trucking companies for haulage, and has restricted movement: daylight hours, no weekends. It is also expensive; for example, rental of an overpack is about $\$ 1500 /$ day.

Because of the controls and the attendant costs, shipments of aged-out $\mathrm{RL}$ devices to a radioactive waste disposal site are generally in Type $A$ packages. Type A packages, each with less than $1000 \mathrm{Ci}$ in the waste contents, can be shipped in a single, exclusive shipment by any trucking company. With tritium-containing $\mathrm{RL}$ devices as the waste, there would be no dose rate to pose a problem with the Type A package (or a Type B package) or limit the number of packages for a shipment; i.e., a truck could be fully loaded.

10 CFR 61 Subpart $D$ gives the technical requirements for land disposal facilities. Section 61.55 defines four classes of wastes - Class A, Class B, 
Class $C$, and greater than Class $C$ - which consider the concentrations of long-lived radionuclides and concentrations of shorter-lived radionuclides for which requirements on institutional controls, waste form, and disposal methods are effective. NRC has provided a Technical Position on Waste Form (Rev 0 , May 1983) that is followed by operators of disposal sites.

U.S. Ecology, Inc. and Chem Nuclear Systems, Inc. provided information on disposal practices at their operated sites for compliance with regulations and the NRC guidance. According to 10 CFR 61.55, RL device waste meets the Class $A$ waste classification if the concentration of tritium in a container does not exceed $40 \mathrm{Ci} / \mathrm{m}^{3}$ (equivalent to $8.3 \mathrm{Ci}$ per $0.21 \mathrm{~m}^{3}$ (55-gal) drum). $C l a s s \mathrm{~A}$ wastes do not require structural stabilization if segregated from Class $B$ or $C$ wastes.

Currently at U.S. Ecology-operated sites, RL lighting devices meeting Class $A$ waste criteria can be layered into a $0.1-\mathrm{mm}$ (4-mil) thick plastic liner along with any cushioning material within a drum. The liner is sealed with tape and the drum is closed and later placed into a disposal trench. $C l$ ass $A$ wastes are segregated from Class $B$ and $C l a s s ~ C$ wastes in burial trenches. If tritium exceeds $40 \mathrm{Ci} / \mathrm{m}^{3}$, the waste falls into $\mathrm{Class} B$. The $C l a s s \mathrm{~B}$ package must maintain its structural stability for 300 years. There is no upper limit in $\mathrm{C} i$ of tritium for a Class $B$ waste at the $U$. S. Ecologyoperated sites. The normal requirement applicable for non-agreement states for disposal of waste in a gaseous form is that the total activity must not exceed $100 \mathrm{Ci}$ per container (10 CFR 61.56(a)(7)). If at any time a tritiumcontaining liquid waste were to be disposed of, it would have to be solidified or packaged in sufficient absorbent material as required by 10 CFR 61.56(a) $(2$ and 3 ).

At the Barnwell site, which is in an agreement state, there also is no upper limit on the total $\mathrm{Ci}$ content per package for disposal, but if a package to be shipped contains greater than $1000 \mathrm{Ci}$, the package would need to be placed in an NRC Type B container for transport over public highways to Barnwell. In general at the Barnwell site, there are three restrictions on the disposal of instruments and articles containing tritium gas: 
- Maximum activity per source is limited to $50 \mathrm{Ci}$. A single device may exceed $50 \mathrm{Ci}$, as long as each individual source is less than or equal to $50 \mathrm{Ci}$.

- Maximum pressure of the gas in the source may not exceed $150 \mathrm{kPa}$ (1.5 atmospheres).

- Disposal packaging and/or the waste form must meet stability requirements for Class B waste.

Because tritium is used in the gaseous state, RL lights are characterized as unstable waste and the waste form and disposal practices must ensure structural stability. For Class $B$ unstable wastes, high-integrity containers (HICS) are used to provide the structural stability under the rigors of the disposal environment. Unstable materials can be placed irito HICs of appropriate size and sent to a disposal site, each of which can handle HICs.

The Barnwell site uses polyethylene HICs, ranging in size from 0.29 to $3.40 \mathrm{~m}^{3}$ (10.2 to $\left.120 \mathrm{ft}^{3}\right)$, which have been approved by the State of South Carolina. Alternately, a $0.21-\mathrm{m}^{3}(55-\mathrm{gal})$ drum could be used. A mold of special concrete could be formed in the drum to surround the disposed items. Following placement into the drum, the contents would be topped with concrete. Chem Nuclear has a NRC-approved formula for the cement. The polyethylene HICS are $p$ iaced into a concrete overpack or caisson in a stable trench for Class $B$ and $C$ wastes. At sites other than Barnwe11, Class $B$ and $C 1$ ass $C$ wastes are placed $15 \mathrm{~m}$ below ground level. Due to the high water table level at the sarnwell site and the consequent shallower placement of a container, a concrete cap must be placed over the waste to prevent inadvertent intrusion.

A Barnwell polyethylene HIC cannot be buried at the other radioactive waste disposal sites because it would not be stable to the compressive load at the required $15-m$ depth. Stainless steel HICs are used at these other sites and they are just placed onto the trench floor where they are ultimately covered by backfill.

These are the practices as of September 1990. The Chemical Nuclear Inc. representative pointed out that the rules are always changing, and it is unknown how the state compacts will act once they are fully operative. 


\subsection{ALTERNATIVE TO DISPOSAL: EOL TRITIUM RECOVERY FROM RL DEVICES}

As an alternative to disposing of EXIT signs and other RL devices at the end of their lives, the glass RL light tubes could be removed from the devices, and the iritium released into an enclosed system, collected, purified, packaged, and recycled back to industry for use. A recovery and recycling process is currently used by an English firm; another process has been conceptualized by EG\&G Mound Applied Technologies. Information on each process is summarized below.

\subsection{RECOVERY IN ENGLAND}

The recovery process of the English firm is proprietary, but it does involve crushing the glass RL light tubes followed by recovery and storage of tritium on an uranium bed. A number of steps which were not revealed are involved. The gas release method is described in Section 4.3.1.4. The process was reported as working well, being marginally cost effective, and being fully approved by the United Kingdom. Although a small amount of tritium is retained by the glass particles, the residuals of the process can be disposed of as low-level radioactive waste. ALARA practices are followed throughout.

\subsection{CONCEPTUALIZED TRITIUM RECOVERY PROCESS}

Systems have been conceptualized at ORNL (Figure 4.1) and at Mound for recovering and reprocessing of tritium from $\mathrm{RL}$ device components having reached their end-of-life. The Mound design includes recovery of the tritium, separation of the tritium from impurities and enrichment of the recovered tritium to the $99+$ mo $1 \%$ level for recycle within the RL device fabrication industry. Another aspect that has been evaluated includes the cost of reprocessing the various types of signs known to be in the inventory. $A$ discard limit for tritium remaining in solid waste was computed considering economic factors of the reprocessing scheme; no weighting factor for environmental considerations was employed. 


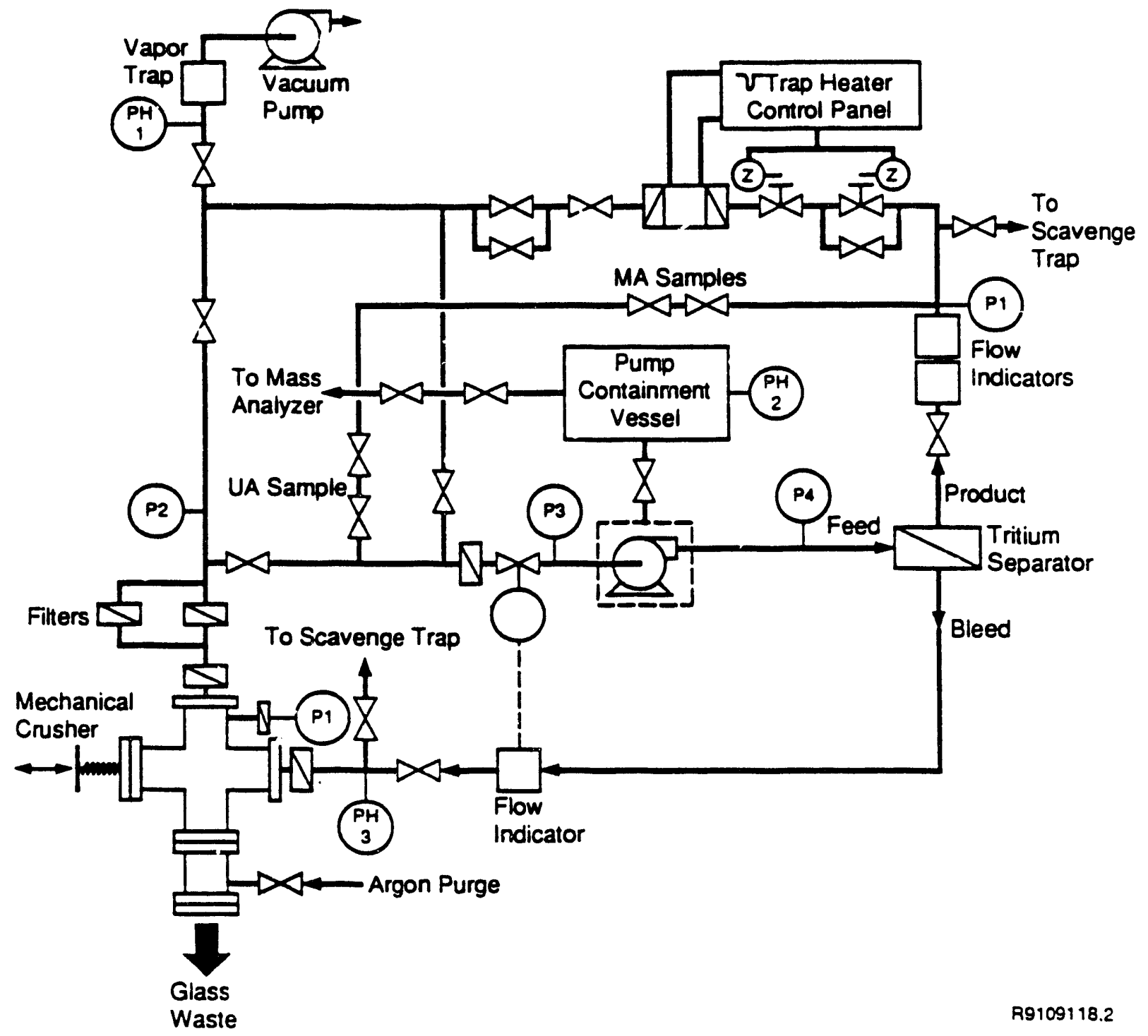

FIGURE 4.1. Oak Ridge Design for a Tritium Recovery System with Manual Tube Crushing Fixture

Key process steps of the Mound concept are summarized in the following:

- Disassembling signs for removal of the sealed tritium-powered RL light tubes.

- Calorimetering the glass tubes to accouni for tritium received.

- Loading the glass tubes into a sealed chamber of a hydraulic crusher and evacuating the chamber. 
- Crushing the tubes to release tritium gas into the chamber.

- Pumping the gas through a liquid nitrugen-cooled trap to freeze out impurities such as water vapor, methane, and ammonia which accumulate in time during long-term storage. The frozen-out compounds later would be warmed, released, and then collected and effectively dissociated on a bed of uranium metal; carbon, oxygen, and nitrogen form permanent compounds with uranium; uranium hydrides are reversibly dissociable.

- Collecting the pumped gas in a holding tank of known volume and determining the quantity and quality of released gas by pressure-volumetemperature (PVT) relationships and mass spectroscopy (MS) for accountability comparison of the tritium coriceni in the devices received and determination of recovery efficiency.

- Enriching the recovered tritium to $99+$ mol\% for recycle within the RL device manufacturing industry. This enrichment involves absorption of hydrogen isotopes tritium, deuterium, and protium on a uranium bed and pumping off helium-3; cryogenic distillation of the desorbate to isotopically enrich tritium to $90+\mathrm{mol} \%$; and a final processing step using thermai diffusion to obtain $99+$ mol\% tritium.

\subsubsection{Categories of RL Tubes}

For purposes of devising tritium recovery mechanisms and estimating recovery costs, quantity, and value of iritium to be recovered, tritium devices can be divided into four categories of gas-filled devices according to their tritium content and two categories of solid-state devices.

\subsubsection{Gas-Filled RL Devices}

The category with the least tritium consists of small device with less than $1 \mathrm{Ci}$ per device. These devices are used for backlighting instrument dials (e.g. reticules in gun sights) and have been used for illumination of liquid crystal displays on watchos.

The second category is the 1 - to $2-\mathrm{Ci}$ devices used for backlighting scales on inclinometers for mortars and howitzers and to make personnel markers for the military. Some manufacturers spell "EXIT" with 1- to 2-Ci segments.

The third category is the 5- to $10-\mathrm{C} i$ tubes used as lighting segments of aircraft and commercial EXIT signs and for aiming post devices and map reading lights for the miiitary. 
The fourth category is the 30- to $166-\mathrm{Ci}$ tubes used for airfield runway lighting, taxiway signage panels, and signal wands.

\subsubsection{Solid-State RL Devices}

A new generation of solid-state tritium devices when fully developed will probably fall into three categories for tritium recovery purposes: Devices using glass microspheres, inorganic devices, and organic devices. The recovery method employed may be different for these three types. Because the actual form that the device might take is unknown at this time, it is difficult to speculate concerning a method for tritium recovery. However, recovery of tritium from plastic or inorganic sources would be expected to be more complex, difficult, and costly than the methods described here.

\subsubsection{Expected Composition of Gas from RL Tubes}

Two studies of the gas composition in small (2- and 8-Ci) commercial and (50-Ci) ORNL tritium devices have been performed at Mound since 1984. The findings of each study give similar results: The tritium from direct fracture has nearly the expected helium-3 content (implying little loss by diffusion), some protium $(H)$ ingrowth, and a small indication of water vapor present in the gas (see Table 4.1). The sealed glass envelope is a good storage vessel for tritium gas. Residual gas adsorbed on the phosphor accounts for 7 to $20 \%$ of the total tritium and is proportional to the surface-to-volume ratio of the tube. This conclusion is based on data in Tables 4.2 and 4.3 from this study. In Table 4.2 the area-to-volume ratio is 7 and in Table 4.3 the ratio is 20 ; in both device types, the fill pressure is $1.3 \mathrm{~atm}$. These data imply that 80 to $90 \%$ of the tritium can be extracted from lamps by fracture alone without the high-tı:mperature bakeoff to remove the adsorbed tritium.

\subsection{TRITIUM RECOVERY PROCESS}

The tritium recovery and enrichment process hardware is shown schemat $i$ cally in Figure 4.2. The function of the various process segments are a gas release station, gas pumping measurement and cleanup facilities, storage of recovered tritium, ans finally an enrichment facility. The area of greatest variety in design possibility is the gas release station. Other portions of 
TABLE 4.1. Tritium Gas Composition for Various RL Lights

\begin{tabular}{|c|c|c|c|c|c|}
\hline & $\begin{array}{c}\text { Fil1 } \text { Gas }^{(a)} \\
(G 1 \text { ass })\end{array}$ & $\begin{array}{c}\text { Range } \\
\text { Indicator } \\
\end{array}$ & $\begin{array}{c}\text { Aiming } \\
\text { Post } \\
\end{array}$ & $\begin{array}{r}\text { ORNL Tybe } \\
\text { Gas }\end{array}$ & $\begin{array}{l}\text { ORNL Soljjd } \\
\text { Bakeoff }{ }^{(b)}\end{array}$ \\
\hline $\begin{array}{l}N(C i) \\
H(M o 1 \%) \\
D \\
T \\
H e-3 \\
H_{2} \\
H D \\
H T \\
D_{2} \\
D T \\
T_{3} \\
22-T_{2} O \\
24-C^{2} T_{4} \\
28-N_{2} \\
32-O_{2} \\
40-A^{2} \\
44-C_{2}\end{array}$ & $\begin{array}{r}6.66 \\
0.66 \\
0.87 \\
92.76 \\
5.56 \\
0.02 \\
>0.05 \\
1.28 \\
<0.02 \\
1.73 \\
91.26 \\
0.01 \\
0.15 \\
<0.01 \\
<0.01 \\
<0.01 \\
<1.0\end{array}$ & $\begin{array}{r}0.68 \\
6.96 \\
0.90 \\
83.25 \\
7.08 \\
0.46 \\
0.15 \\
12.84 \\
<0.02 \\
1.64 \\
76.02 \\
0.31 \\
1.47 \\
0.02 \\
<0.01 \\
0.01 \\
<0.01\end{array}$ & $\begin{array}{r}4.74 \\
5.14 \\
1.02 \\
92.52 \\
2.24 \\
0.36 \\
<0.05 \\
9.56 \\
<0.02 \\
2.04 \\
85.57 \\
0.03 \\
0.20 \\
<0.01 \\
<0.01 \\
<0.01 \\
<0.01\end{array}$ & $\begin{array}{r}36.57 \\
2.20 \\
0.84 \\
69.97 \\
26.72 \\
0.00 \\
<0.05 \\
4.37 \\
<0.02 \\
1.65 \\
66.05 \\
0.20 \\
0.38 \\
0.10 \\
<0.01 \\
0.08 \\
0.05\end{array}$ & $\begin{array}{r}3.41 \\
27.60 \\
0.77 \\
60.41 \\
3.56 \\
14.50 \\
0.29 \\
25.92 \\
<0.02 \\
1.23 \\
46.84 \\
0.55 \\
0.01 \\
5.65 \\
0.03 \\
0.23 \\
1.57\end{array}$ \\
\hline
\end{tabular}

(a) Fill gas sealed and stored in a spherical glass envelope by a vendor.

(b) Two analyses of same ORNL tube: one as free gas and one as gas absorbed on solid.

the recovery system have good reference prototypes from many tritium handling applications, but gas release from phosphor-filled glass tubes is unique to this recovery operation.

\subsubsection{Gas Release Methods}

Five types of gas release methods were evaluated for the processing of large numbers of devices: high-temperature vacuum baking; laser drilling to vent gas into a recovery chamber; fracture of lamps by ball milling; vacuum grinding; and fracture of devices in a hydraulic crushing fixture. Each of these gas release methods are described and analyzed in the following paragraphs. 
TABLE 4.2. Comparison of Total Tritium in RL Devices by Calorimetry and PVT/MS Analysis of Gas Released on Fracture (no bakeoff). The difference between calorimetry and PVT/MS is a measure of tritium on the walls. Residual on the walls is proportional to the ratio of surface area to volume (A/V).

\begin{tabular}{|c|c|c|c|}
\hline Item & $\begin{array}{l}\text { Calorimetry } \\
\text { (Ci) }\end{array}$ & $\begin{array}{c}\text { PVT/MS } \\
(\mathrm{Ci})\end{array}$ & $\begin{array}{l}\text { Percent on } \\
\text { Walls }(\%)\end{array}$ \\
\hline $\begin{array}{l}\text { Aiming Post (Green) } \\
\text { Aiming Post (Orange) } \\
\text { Range Indicator (GRN) } \\
\text { Range Indicator (GRN) } \\
\text { Range Indicator (GRN) } \\
\text { Range Indicator (GRN) }\end{array}$ & $\begin{array}{l}8.39 \pm 0.04 \\
7.89 \pm 0.06 \\
0.55 \pm 0.05 \\
0.59 \pm 0.05 \\
0.71 \pm 0.03 \\
0.73 \pm 0.05\end{array}$ & $\begin{array}{l}8.13 \pm 0.12 \\
7.53 \pm 0.11 \\
0.49 \pm 0.01 \\
0.49 \pm 0.01 \\
0.65 \pm 0.01 \\
0.60 \pm 0.01\end{array}$ & $\begin{array}{r}3 \\
5 \\
11 \\
17 \\
8 \\
18\end{array}$ \\
\hline
\end{tabular}

\subsubsection{High-Temperature Vacuum Bakeout}

High-temperature vacuum baking has been used at Mound to recover a large quantity of gas from thousands of watch back-1ight tubes (250 $\mathrm{mCi}$ per tube) and other small tubes used for exit signs that came from the reclamation of the inventory of the American Atomics manufacturing facility in Tucson, Arizona. The recovery method consists of batch loading of tubes into a stainless steel cylinder $6.5 \mathrm{in}$. in diameter and $14 \mathrm{in}$. long. When filled with tubes, a lid with a pumping line was welded on. The unit was calorimetered, baked at $650^{\circ} \mathrm{C}$, and the tritium that diffused through the softened glass was pumped into tanks for quantitation by PVT measurements and gas analysis by mass spectrometry. Residual tritium left in the glass waste after baking was again measured by calorimetry. Collection efficiency was $80 \%$ for EXIT sign tubes and 60 to $80 \%$ for the watch light tubes. The batch container then became the burial container. The method works and is currently available but it is expensive because a separate stainless steel contairier is used for each batch (see cost estimate in Table 4.7). Additionally, the method works best with very clean devices where mounting adhesives or potting compounds have been removed. If they are not removed, the organics are thermally decomposed and the tritium preferentially replaces the hydrogen in the organics. The organic vapors evolved from the vessel condense in cooler lines outside the heated vessel and are not recovered. This can lead to low collection efficiencies and eventually plugged lines. If it is desirable to 
TABLE 4.3. Tritium Content of ORNL 10 in. $\times 1 / 2$ in. Tubes. Gas released during room temperature fracture and additional gas released during a $500^{\circ} \mathrm{C}$ bakeoff of the tube.

\begin{tabular}{|c|c|c|c|c|c|}
\hline Tube No. & $\begin{array}{r}\text { Gas, } n_{\mathrm{g}} \\
\mathrm{Cm}^{3}(\text { STP })\end{array}$ & $\begin{array}{c}\text { Tritium, } \\
\text { Mol\% }\end{array}$ & $\begin{array}{l}\text { Solid, } n_{s} \\
\mathrm{Cm}^{3}(S T P)\end{array}$ & $\begin{array}{c}\text { Tritium, } \\
\text { Mol\% }\end{array}$ & $\begin{array}{l}\text { Tritium, } T_{\text {so }} \\
\% \text { on Solid }\end{array}$ \\
\hline $\begin{array}{r}1 \\
2 \\
3 \\
4 \\
5 \\
6 \\
7 \\
8 \\
9 \\
10 \\
11 \\
12 \\
13 \\
14 \\
15 \\
16 \\
17 \\
18 \\
19 \\
20 \\
21 \\
22 \\
23 \\
24 \\
25 \\
26 \\
27 \\
28\end{array}$ & $\begin{array}{l}15.93 \\
15.18 \\
15.76 \\
13.04 \\
17.42 \\
19.50 \\
18.93 \\
18.22 \\
19.43 \\
19.39 \\
16.43 \\
15.04 \\
12.56 \\
13.27 \\
18.70 \\
17.22 \\
18.34 \\
18.01 \\
15.44 \\
14.21 \\
13.01 \\
14.29 \\
18.10 \\
13.77 \\
18.84 \\
20.07 \\
18.01 \\
18.98\end{array}$ & $\begin{array}{l}68.55 \\
67.81 \\
69.44 \\
65.98 \\
70.70 \\
69.67 \\
71.40 \\
74.73 \\
70.60 \\
71.29 \\
68.16 \\
68.90 \\
69.56 \\
68.72 \\
69.18 \\
66.98 \\
72.41 \\
72.98 \\
66.36 \\
67.20 \\
67.63 \\
67.47 \\
65.29 \\
69.21 \\
71.46 \\
71.16 \\
71.49 \\
68.38\end{array}$ & $\begin{array}{l}1.74 \\
1.90 \\
1.65 \\
1.98 \\
2.11 \\
1.89 \\
2.02 \\
1.81 \\
1.91 \\
2.36 \\
2.23 \\
1.79 \\
2.09 \\
2.32 \\
1.69 \\
1.89 \\
1.52 \\
1.90 \\
1.82 \\
2.06 \\
1.59 \\
2.65 \\
2.15 \\
1.30 \\
1.98 \\
1.23 \\
1.71\end{array}$ & $\begin{array}{l}52.76 \\
55.35 \\
56.60 \\
56.32 \\
60.41 \\
58.95 \\
62.17 \\
61.87 \\
63.49 \\
55.17 \\
49.90 \\
53.08 \\
47.38 \\
49.25 \\
56.69 \\
40.71 \\
50.22 \\
57.82 \\
48.43 \\
47.84 \\
59.78 \\
51.88 \\
45.17 \\
44.46 \\
43.28 \\
41.03 \\
65.15\end{array}$ & $\begin{array}{r}8.2 \\
8.8 \\
9.8 \\
8.3 \\
8.6 \\
7.6 \\
8.4 \\
7.5 \\
8.1 \\
10.4 \\
9.7 \\
9.6 \\
9.8 \\
8.1 \\
7.7 \\
5.5 \\
5.5 \\
7.7 \\
8.4 \\
10.1 \\
9.0 \\
10.4 \\
9.3 \\
4.1 \\
5.7 \\
3.8 \\
7.9\end{array}$ \\
\hline $\begin{array}{l}\text { Average } \\
\text { Std. Dev. }\end{array}$ & $\begin{array}{c}16.68 \\
2.3\end{array}$ & $\begin{array}{r}69.39 \\
2.19\end{array}$ & $\begin{array}{l}1.90 \\
0.30\end{array}$ & $\begin{array}{r}53.15 \\
6.84\end{array}$ & $\begin{array}{l}8.1 \\
1.8\end{array}$ \\
\hline
\end{tabular}

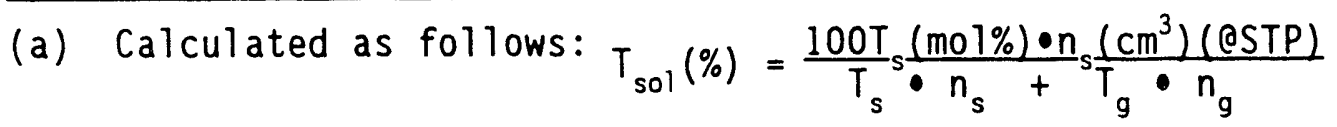

recover tritium from small tubes $(<1 \mathrm{C} i)$ to minimize tritium going to the environment regardless of cost, this bakeout method is effective. 


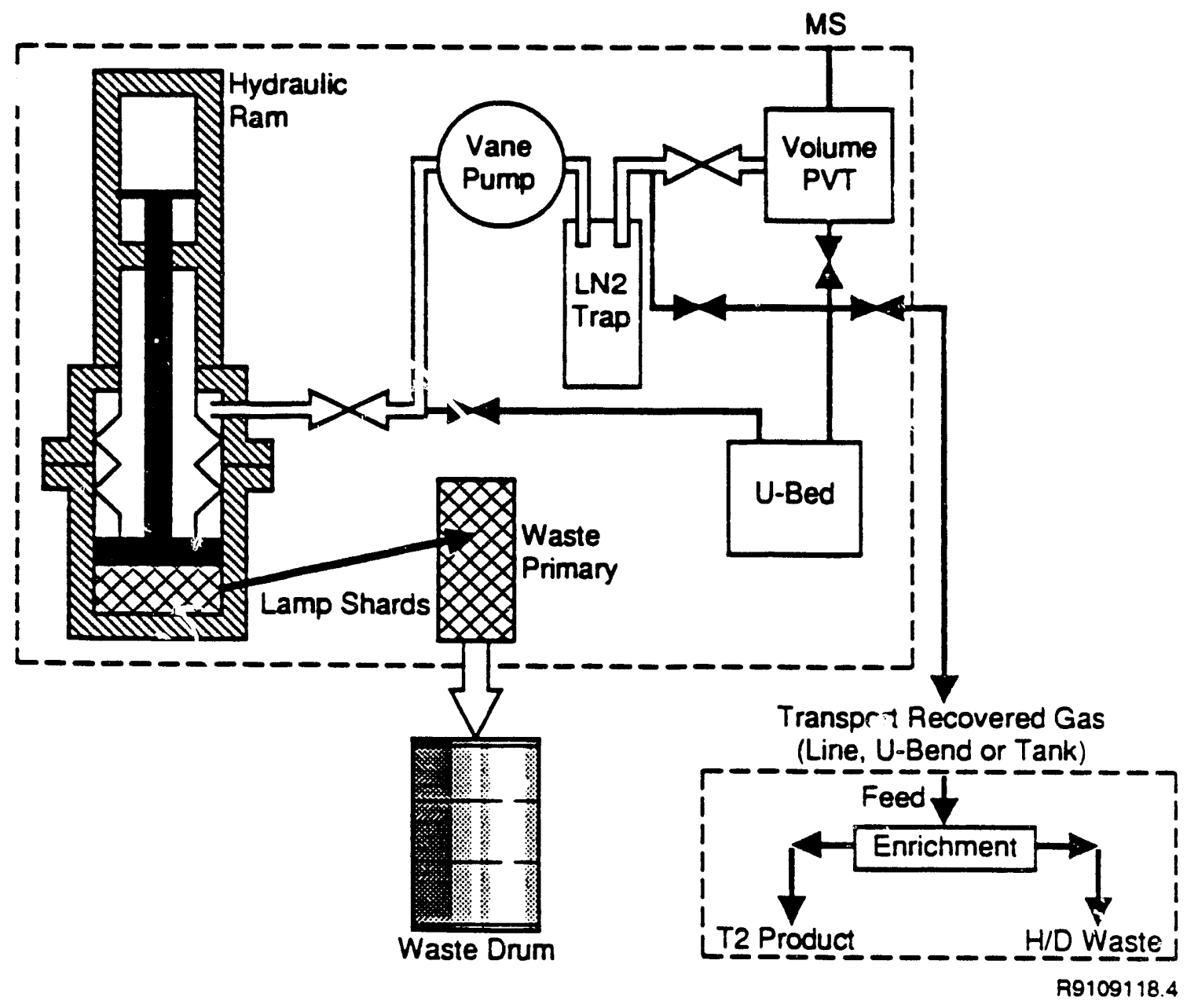

FIGURE 4.2. Cas Release, Purification and Tritium Enrichment $\because$ acilities (Ellefson and Carden)

\subsubsection{Laser Drilling to Vent Tubes For Gas Recovery}

A method that minimizes the release of contamillated phosphors and glass shards is the laser drilling of tritium tubes to vent the gas to a collection volume and pumping system. This method would require a capture vessel with a window to allow the laser beam into the vessel. A difficulty with this method is ensuring that each individual tube in a batch is vented. It requires aiming at each tube while some of the tubes are shielded by other tubes. Because laser venting very labor intensive compared with other fracture methods, it is not very practical. To date it has not been tried as a recovery method. 


\subsubsection{Ball Milling of Glass Tubes to Fracture For Gas Recovery}

A method for fracturing a batch of glass tubes is to use a large cylinder with 1 -in. to 2-in. steel balls placed in the bottom and the tritium tubes placed on top to fill the cylinder about $60 \%$ full. The lid with a valve on top is sealed on top of the cylinder. The cylinder is rolled on its side for a sufficient time (determined experimentally) to ensure that all the tubes are broken before pumping off the tritium gas from the cylinder. The shards are then dumped into a waste cylinder for tritium measurement and burial. There are some risks with this design. In loading the cylinder, care must be taken to ensure that the balls do not shift during loading and fracture a tube before the 1 id is put on. Secondly, there is no assurance that all the tubes are broken when the lid is removed. In fact, an intact tube may be weakened by the abrasion and may fracture in the dumping of waste. This uncertainty of performance makes this an undesirable candidate.

\subsubsection{Vacuum Grinder That Releases the Gas and Pulverizes the Tubes}

A vacuum grinding apparatus has been used at a device manufacturer in England, for reclamation of tritium from tubes. The design is a vacuum-sealed hopper over the entrance to a coarse grinder with the pulverized glass and phosphor falling to the bottom of the grinder chamber (within the same vacuum). Tritium tubes for reclamation are placed in the hopper and the batch is sealed. The grinder is turned on and the system run until no further sounds of breaking pieces of glass can be heard. Tritium is pumped away as it is released. A problem with this system is that extensive tritium-contaminated dust is generated as the phosphor is knocked off the glass during pulverizing. Additionally, a good rotating vacuum seal (preferably a magnetically-coupled shaft

feedthrough) is needed to keep glovebox tritium levels down. With the wrong design it is possible that some tube sizes could get wedged above the grinder so they would not fall in.

\subsubsection{Hydraulic Ram Fracture Device For Gas Recovery}

Existing processes (Sections 4.3.1.1 and 4.3.1.4) for recovering tritium from RL tubes were evaluated during the early phase of this study. The hightemperature vacuum bake consumes expensive containers with each batch, and the 
vacuum grinding presents a higher risk for release of tritium to operating personnel and to the environment than was felt to be acceptable. Therefore, the ORNL manual crushing facility (Figure 4.1) and the crushing fixtures at Mound were examined as a possible method for gas release. A design that evolved from the evaluation process appears to present a reasonable compromise between economics and safety, i.e., high throughput capability with a minimum environmental risks. It must be noted, however, that to realize the lowest environmental risks, the system must be operated within an inert glovebox line. The central feature of the preferred recovery scheme is a large vacuum(bellows) sealed hydraulic cylinder used to fracture positively each of many glass tubes so that the encapsulated gases expand into a chamber before being transferred for further processing. Once the tritium and other gases have been pumped away, the same hydraulic ram is used to crush the glass into shards to compact the waste for either direct burial or bakeoff of adsorbed gases depending upon residual tritium concentration. Processing of residuals is discussed later in the section on cost analysis.

\subsubsection{Operational Steps in the Recovery of Tritium from RL Tubes}

$A$ number of individually identifiable operations make up the process of total tritium recovery from RL tubes. The specific operation steps were identified earlier and are addressed separately so as to present a comprehensive view of the total reclamation system and to make the cost assessment flow in a more logical sequence. Figure 4.3 shows a block diagram of the total reclamation and tritium recovery scheme. Discussion of these operations steps will be in the following order:

1. Collection of $\mathrm{RL}$ devices

2. Disassembly of devices

3. Tritium inventory (accountability in)

4. Loading of tubes into chamber

5. Fracture of tubes and recovery of gas

6. Gas cleanup

7. Product gas analysis (PVT/MS) 
8. Collection and packaging of glass shards

9. Tritium inventory (accountability out)

10. Tritium enrichment.

\subsubsection{Collection of RL Devices}

Upon arrival at a processing site, the RL devices must be collected in an assemuly area where they can be conveniently stored in an environmentally safe manner until disassembled. This would require that the storage facility be equipped with room monitors and single-pass ventilation to a stack. One site (Mound) has in some laboratory areas ventilation system controls to isolate the room exhaust from discharge to the stack in the event of the rupture of a tube containing a Curie load which would result in the discharge of tritium at a level greater than the permissible room level, $10 \mu \mathrm{Ci} / \mathrm{m}^{3}$.

\subsubsection{Disassembly of Devices}

The tubular elements containing the tritium must be removed from the devices before performing the analytical measurements on received tritium. This step is to remove the cover to expose the glass tubes. This is a relatively labor intensive operation; however, it is necessary because the physical size of the devices prohibits them from fitting into an outer container that protects the analytical measuring system. This protection is needed in case one of the glass tubes ruptures and releases tritium within the instrument. The sequence of disassembly would be:

1. Pass device into a glovebox.

2. Saw or drill the device to remove the clear cover exposing the tritium tubes.

3. Remove the tubes by cutting the adhesive that mounts them.

4. Collect the tubes in a vessel or plastic bag until a quantity that fills the calorimeter can is accumulated.

5. Bag and pass out of the glovebox the wastes from the device.

It should be noted here that some devices have a clear silicone potting compound applied to the glass tubes to physically hold them in position within 


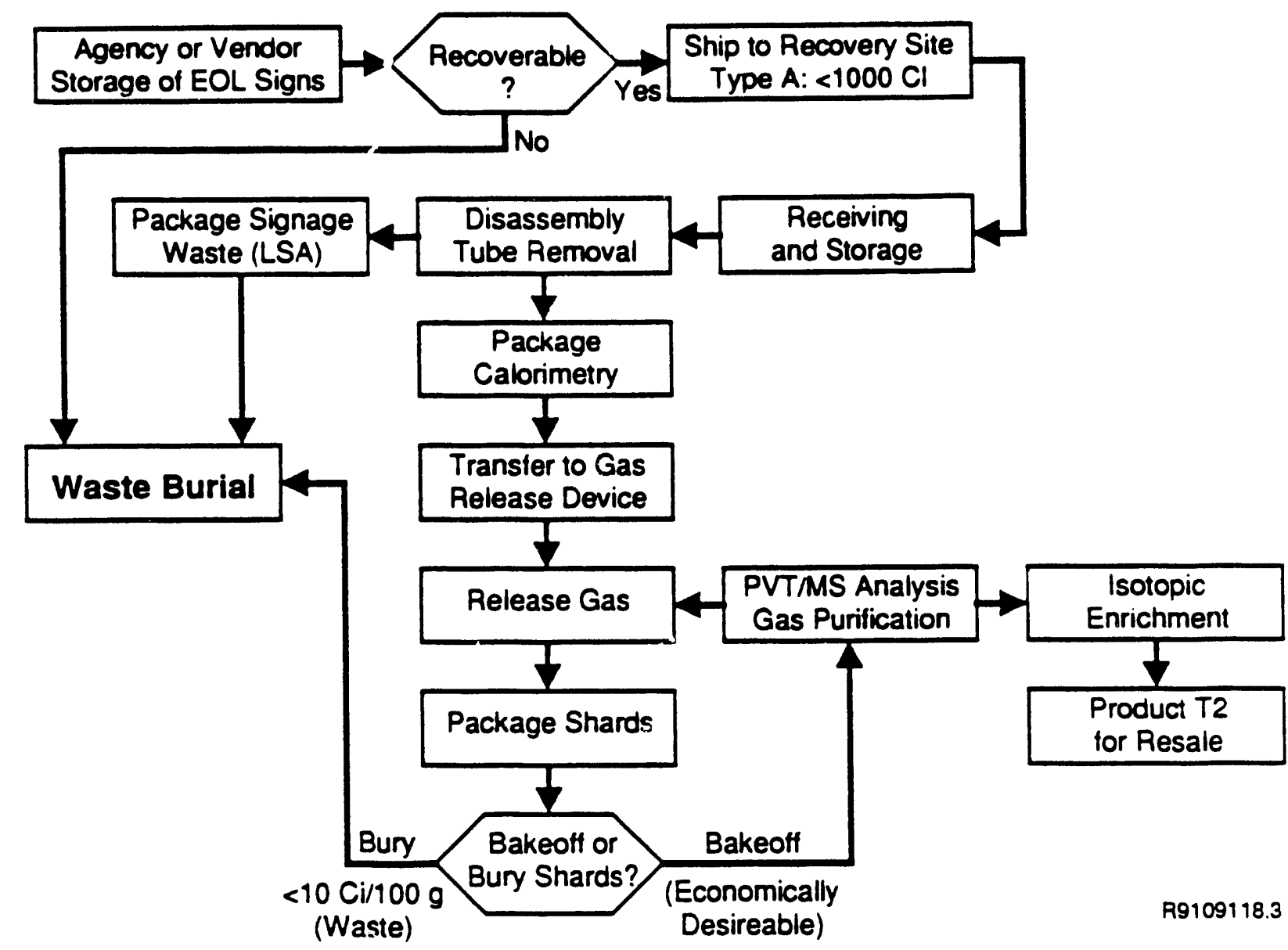

FIGURE 4.3. Mound Flow Diagram of Activities for Recovery and Enrichment of Tritium from End-of-Life RL Light Tubes

the device. This compound will have to be stripped by mechanical methods to the greatest extent possible or be dissolved. Commercial solvents (for example Dynaloy Uresolve Plus 500) are available that are effective for dissolving the compound, which contains ethylene glycol monomethyl ether and potassium hydroxide). However, the high probability of having a broken or leaking tube while using the compound would result in a tritiated solvent. The tritiated solvent would be a radioactive mixed waste material. There is no disposal mechanism currently available for radioactive mixed wastes; thus, this method for removal of silicone potting compound is to be avoided. 


\subsubsection{Tritium Accountability. In}

EXIT signs and other tritium containing devices shipped in for recovery are first received by an item count. The ages of the devices are different and probably not well known, so the real tritium content is only an estimate.

Calorimetry is the analytical method of choice for determining the incoming tritium for accountability purposes. As a nondestructive technique, it consumes none of the material it measures, a basic requirement for an accountability measurement method. The operating parameters of calorimetry present some requirements that must be met: 1) no chemical reactions can be in progress since they produce heat, and 2) the sample being measured must fit into a containment vessel specifically built to fit a given calorimeter which is in a fixed location within a temperature-controlled environment.

The tubes stripped from the devices must be loaded into the containment vessel by hand to avoid breakage. The vessel is then sealed and transported to the calorimetry facility for analytical measurements to determine the incoming tritium value. Permanent records of the measured quantity must be kept to keep track of the inventory of tritium and for later use to determine the percent recovery.

\subsubsection{Loading of Tubes into Chamber}

Following accountability measurements of a batch of tubes, the individual tubes are loaded into the sealed hydraulic cylinder and ram system. The cylinder is designed to accommodate a variety of tube sizes. A cylinder with a $20.65-\mathrm{cm}$ (9-in.) diameter can accommodate 80 of the $1.9-\mathrm{cm}-(3 / 4-$ in.) diameter glass tubes (airfield RL panel elements), which contain approximately $7000 \mathrm{Ci}$, assuming $166 \mathrm{Ci}$ initial loading and one half life old. Once loaded with tubes, the cylinder is sealed and evacuated to approximately $3 \mathrm{~Pa}$ (20 $\mathrm{m}$-torr).

\subsubsection{Fracture of Tubes and Recovery of Gas}

The function of the ram mechanism is to positively fracture the tubes so that the tritium can expand into the free volume of the evacuated chamber and be pumped into a product holding tank of known volume. Pumping is continued until the ram chamber pressure is again in the 1 to $3 \mathrm{~Pa}$ range. At that 
pressure the hydraulic ram mechanism is isolated from the system and vented to the glovebox environment in preparation for the next loading of tubes.

\subsubsection{Gas Cleanup}

Long-term storage combined with processing of the tritium through fabrication and recovery systems inevitably results in the generation of impurities in the recycled tritium. Tritium exchanged with protium in residual impurities such as water vapor, methanes, and ammonias will accumulate with time. These tritiated impurities can be removed from the product stream by inserting a cold trap (liquid nitrogen) between the transfer pump and the product holding tank. The compounds that are frozen within the cold trap can be released by warming the trap the compounds on a bed of uranium metal. The hydrogen forms uranium hydrides (reversibly dissociable) and the carbon, oxygen, and nitrogen form permanent compounds with the uranium. These chemical reactions eventually consume the uranium sites available for hydriding and thus the uranium must be periodically replaced.

\subsubsection{Product Gas Anaiysis (PVT/MS)}

Each batch of gas recovered should be characterized by PVT/MS analysis to track the tritium concentration and quantity from various device types and also for comparison with the accountability-in measurements, which provides a running measure of recovery efficiency. Such an analytical scheme provides valuable information on the process, but it requires that the tritium losses to the analysis be measured; these are estimated to be in the range of $30 \mathrm{Ci}$ per analysis.

\subsubsection{Collect and Package Glass Shards}

Once the product gas has been completely recovered, the broken tubes and shards and the loose powdered phosphors must be removed from the hydraulic press chamber before loading the next batch of tubes for processing. The hydraulic ram is used to pulverize the fractured tubes into smaller shards for better waste compaction. The pulverized glass, phosphors, and residual mounting/potting compound are transferred to a stainless steel container having a fill volume ( $80 \%$ of total volume) of 2.7 liters. Filling this with phosphor/glass shards incorporates about $3 \mathrm{~kg}$ of glass shard waste (estimating 
waste density at $50 \%$ of glass bulk density). At this point a decision is made whether to outgas the shards with heat and additional pumping or to complete the packaging for burial as contaminated trash (see Figure 4.3). The basis for the decision is addressed in Section 4.4 on cost assessment. An economic discard level for this process is $10 \mathrm{Ci} / 100 \mathrm{~g}$ of waste; the tritium in this waste container will be less than $300 \mathrm{Ci}$. In either case, the final step is to weld a stainless steel top onto the container to permanently seal it prior to removing the assembly from the boxline for decontamination, calorimetry, final packaging, and burial.

\subsubsection{Iritium Inventory (Accountability-Out)}

Accurate records of the quantity of tritium recovered from the recycle system must be maintained for accountability purposes. This function can be accomplished in either of two ways: 1) by comparison of the T-[Recovered] (grams)/T-[In] (grams) ratio, i.e., PVT/MS-value/calorimetry-In, which is the recovery efficiency, or 2 ) by reacting the recovered tritium onto a removable uranium storage bed. The uranium bed would be calorimetered to obtain the value of tritium recovered. By summing appropriate batches recovered and waste values of tritium and comparing the recovered values to the sum of the calorimetry values "In," an efficiency for recovery can be calculated. Recovery efficiencies of $90 \%$ or greater are expected for large tubes.

After the accountability data are obtained, the tritium must be transferred to the enrichment facility where it is isotopically re-enriched to $99 \%$. This can be accomplished by reacting the tritium gas with a uranium bed and pumping off the helium overgas. If the enrichment facility is interconnected with the recovery facility where the gas purification occurs, a batch of gas can be pumped to the enrichment facility from the recovery operation while using PVT/MS measurements for accountability purposes.

\subsubsection{Tritium Enrichment}

Data currently available indicate that tritium concentrations in the range of 55 to $80 \mathrm{~mol} \%$ can be expected in the tubes reclaimed from RL devices. This variation comes from the ${ }^{3} \mathrm{He}$ accumulation from the various ages of RL devices expected to be returned. The variation of tritium also depends to a lesser 
extent on the protium $(H)$ ingrowth into the tritium from exchange with $H$ in the device or during recovery processing. These two sources of degradation ( ${ }^{3} \mathrm{He}$ ingrowth and $\mathrm{H}$ ingrowth) require that minimally the ${ }^{3} \mathrm{He}$ be removed by processing and preferably the $H$ and deuterium removed by isotopic enrichment.

The processing for ${ }^{3} \mathrm{He}$ removal is to absorb the tritium (and $H$ and $D$ ) onto a uranium bed and pump off the inert $\left({ }^{3} \mathrm{He}\right)$ overgas. The isotopic enrichment process of choice is cryogenic distillation, which because of the great cost is available only at major tritium handling sites. Mound has such a system in operation that is capable of taking nominally 70 mol\% tritium and enriching that to the $90+$ mol\% level by cryogenic distillation. Further enrichment to $99+$ mol\% tritium is achieved with a thermal diffusion column. This brings the recovered tritium back to the isotopic concentration required for making fresh RL devices.

\subsection{COST ANALYSIS FOR TRITIUM RECOVERY}

A calculation of the costs involved in the recovery of the remaining tritium from each RL device type was performed to gain an understanding of the economics of an operating system. In addition, capital costs for tritium processing facilities were estimated and tritium recovery costs was compared with direct disposal costs.

\subsubsection{Operating Costs}

In estimating operational costs of tritium recovery, assumptions were made on some facets of the reclamation process where no actual information was available for the evaluation. Tables 4.4 through 4.8 show the cost evaluations based on these assumptions.

\section{Amount of Tritium Remaining}

of primary importance is the age of the tritium within the glass tubes. In the absence of this data it was assumed that $50 \%$ of the original tritium remained within the tubes of the smaller devices, i.e., those containing an initial load of $20 \mathrm{Ci}$ or less. Larger signs, i.e., those utilizing 3/4-in.diameter tubes, were assumed to retain $60 \%$ of the initial tritium charge. 
TABLE 4.4. Summary of Operations Costs for Tritium Recovery from End-of-Life RL Devices in Various Commercial Products

\begin{tabular}{|c|c|c|c|c|c|}
\hline $\begin{array}{c}\text { Initial } \\
\text { Curie Load } \\
\end{array}$ & $\begin{array}{l}\text { End-of- } \\
\text { Life } \\
\text { Ci Load }\end{array}$ & $\begin{array}{l}\text { Recovery } \\
\text { Cost, \$ }\end{array}$ & $\begin{array}{l}\text { Burial } \\
\text { Cost, } \$\end{array}$ & $\begin{array}{l}\text { Total } \\
\text { Processing } \\
\text { Cost, \$ } \\
\end{array}$ & $\begin{array}{c}\text { Value of } \\
\text { Tritium } \\
\text { Recovered, } \$\end{array}$ \\
\hline $\begin{array}{l}20 \text { (EXIT signs) } \\
\text { (อ Residuals) } \\
996 \text {-tube panels } \\
\text { (@ Residuals) } \\
100 \text { ( } 3 \text {-tube wand) } \\
100 \text { (2-tube wand) } \\
\text { (@ Residuais) }\end{array}$ & $\begin{array}{r}10 \\
1 \\
598 \\
35 \\
50 \\
75 \\
50 \\
3.5\end{array}$ & $\begin{array}{r}87.08 \\
20.00 \\
235.94 \\
72.02 \\
92.24 \\
92.54 \\
92.24 \\
20.00\end{array}$ & $\begin{array}{c}2.80 \\
\text { (no added cost) } \\
3.60 \\
\text { (no added cost) } \\
1.40 \\
1.40 \\
1.40 \\
\text { (no added cost) }\end{array}$ & $\begin{array}{r}89.88 \\
20.00 \\
239.54 \\
72.02 \\
93.64 \\
93.94 \\
93.64 \\
20.00\end{array}$ & $\begin{array}{r}27.00 \\
3.00 \\
1613.52 \\
105.00 \\
135.00 \\
202.50 \\
135.00 \\
10.50\end{array}$ \\
\hline
\end{tabular}

TABLE 4.5. Cost to Recover Tritium from Exit Signs of $20 \mathrm{Ci}$ or Less

\section{Process Step}

Receiving/Storage
Disassembly
Measure T(Ir) - calorimetry
Load Tubes/Crusher
Fracture/Collect Gas
Collect/Pkg Shards
Measure Shards
Product Gas Analysis
Gas Cleanup/PVT
T Enrichment
Support Hardware

Recovery Cost ${ }^{(b)}$

Burial Cost $\left(0.1 \mathrm{ft}^{3} / \mathrm{sign}\right)$

Recovery/Burial Cost per Sign

Net Cost per Sign
Cost (\$) Manhours (With Overheads) T Valve/Sign ${ }^{(b)}$

$\begin{array}{lr}0.06 & 7.56 \\ 0.40 & 50.40 \\ 0.06 & 7.56 \\ 0.02 & 2.52 \\ 0.03 & 3.78 \\ 0.01 & 1.26 \\ 0.03 & 3.76 \\ 0.01 & 1.26 \\ 0.03 & 3.78 \\ & 1.08 \\ & 4.10\end{array}$

$+\$ 20$ for $\operatorname{HTVB}^{(a)}$

87.08

$\underline{2.80}$

89.88

$27.00^{(c)}$

62.88

\footnotetext{
(a) This cost estimate assumes fracture of the tubes and optimal bakeout. High-temperature vacuum bakeout (HTVB) requires a stainless steel container to collect tubes. Average cost per sign is $\$ 20$.

(b) Low Specific Activity (LSA) waste burial cost at a DOE burial site

(c) Assuming $90 \%$ recovery of the $50 \%$ remaining at EOL at $\$ 3.00 / \mathrm{C}$.
} 
TABLE 4.6. Cost to Recover Tritium in Residuals

\section{Process Step}

\author{
Heat shards and circulate $D_{2}$ \\ Remove shards from crusher \\ Low Purity gas analysis \\ Low Purity gas cleanup/PVT \\ Low enrichment $<35 \%$ - $>99 \%$ \\ For small signs (20-Ci tube) \\ Recovery cost/value for $1.0 \mathrm{Ci}$ \\ For larger signs ( $\mathrm{six} 166-\mathrm{Ci}$ tubes) \\ Additional Labor
}

Recovery cost/value for $35 \mathrm{Ci}$
Time/Cost Per Sign Cost (\$) Manhours With Overhead

T Value

0.05

6.30

0.033

4.15

0.016

0.033

2.01

4.16

$\underline{3.37}$

20.00

3.00

$\underline{52.02}$

72.02

105.00

TABLE 4.7. Cost to Recover Tritium from USAF 6-Tube Panels

Process Step

Receiving/Sturage

Disassembly

Measure T(In) - Calorimetry

Load Tubes/Crusher

Fracture/Collect Gas

Collect/Pkg Shards

Measure Shards (cal)

Product Gas Analysis

Gas Cleanup/PVT

T Enrichment

Support Hardware

Recovery Cost

Burial Cost $\left(0.13 \mathrm{ft}^{3} / \mathrm{sign}\right)(\mathrm{b})$

Recovery/Burial Cost per Panel

Recovery of residual $T_{2}(35 \mathrm{Ci})$

Profit per panel $=\$ 1373.98$

Net profit for residual $T_{2}=\$ 32.98$

Total Profit $=\$ 1.406 .96$

Time/Cost Per Panel
Cost (\$)
Manhours With Overhead I Value/Panel

0.06

0.3

0.02

0.03

0.01

0.03

0.01

0.03
7.56
100.80

37.80

2.52

3.78

1.26

3.78

1.26

3.78

69.30

4.10

$+\$ 50$ for HTVB(a)

235.94

3.60

239.54

$1.613 .52^{(c)}$

72.02

105.00

(a) This cost estimate assumes fracture of the tubes and optional bakeout. High-temperature vacuum bakeout (HTVB) requires a stainless steel container to collect tubes. Average cost per panel is $\$ 50$.

(b) Low Specific Activity ( $L: A)$ waste burial cost at a DOE burial site.

(c) Panels contain six 166- $\mathrm{Ci}$ tubes (996 $\mathrm{Ci}$ total). Recovery value assumes $90 \%$ recovery of $60 \%$ remaining tritium at EOL at $\$ 3.00 / \mathrm{Ci}$. 
TABLE 4.8. Cost to Recover Tritium from ORNL Light Wands

Light wands are manufactured in two configurations, 3-tubed with 150 total $\mathrm{Ci}$ at fabrication and 2 -tubed with $100 \mathrm{Ci}$ at fabrication. All of these are of the 3/4-in.-diameter $\times 10-i n .-7 e n g t h$ tube size.

\begin{tabular}{|c|c|c|c|}
\hline \multirow[b]{2}{*}{ Process Step } & \multicolumn{3}{|c|}{ Time/Cost Per Wand } \\
\hline & \multirow[b]{2}{*}{$\begin{array}{c}\text { Manhours } \\
0.06 \\
0.30 \\
0.15 \\
0.02 \\
0.03 \\
0.01 \\
0.03 \\
0.01 \\
0.03\end{array}$} & $\begin{array}{c}\text { Cost (\$) } \\
\text { With Overhead }\end{array}$ & I Value/Wand \\
\hline $\begin{array}{l}\text { Receiving/Storage } \\
\text { Disassembly } \\
\text { Masure } T \text { (In) - calorimetry } \\
\text { Load Tubes in Crusher } \\
\text { Fracture and Collect Gas } \\
\text { Collect and Pack Shards } \\
\text { Measure Shards } \\
\text { Product Gas Analysis } \\
\text { Gas Clean-up } \\
T \text { Enrichment } \\
\text { Support Hardware }\end{array}$ & & $\begin{array}{r}7.56 \\
37.80 \\
18.90 \\
2.52 \\
3.78 \\
1.26 \\
3.78 \\
1.26 \\
3.78 \\
5.40 \text { for } 3 \\
5.70 \text { for } \\
0.50+\$ 2\end{array}$ & $\begin{array}{l}\text {-Ci tubes } \\
-C i \text { tubes } \\
\text { for } \text { HTVB }(\mathrm{a})\end{array}$ \\
\hline $\begin{array}{l}\text { Total Cost: for } 33-\mathrm{Ci} \text { tubes } \\
\text { Total Cost: for } 50-\mathrm{Ci} \text { tubes }\end{array}$ & & $\begin{array}{l}92.24 \\
92.54\end{array}$ & \\
\hline Burial Costs $\left(0.05 \mathrm{ft}^{3} /\right.$ wand $)$ & & 1.40 & \\
\hline $\begin{array}{l}\text { Total Cost: for } 33-\mathrm{Ci} \text { tubes } \\
\text { Total Cost: for } 50-\mathrm{Ci} \text { tubes }\end{array}$ & & $\begin{array}{l}93.64 \\
93.94\end{array}$ & $\begin{array}{l}135.00 \\
202.50\end{array}$ \\
\hline $\begin{array}{l}\text { Net profit per wand for } 33-\mathrm{Ci} \text { tubes } \\
\text { Net profit per wand for } 50-\mathrm{Ci} \text { tubes }\end{array}$ & & $\begin{array}{r}46.34 \\
108.56\end{array}$ & \\
\hline
\end{tabular}

(a) This cost estimate assumes fracture of the tubes and optional bakeout. High-temperature vacuum bakeout (HTVB) requires a stainless steel container to collect tubes. Average cost per wand is $\$ 25$.

This assumption is based primarily on the fact that larger devices are used in the most recent applications of this light tube technology, and therefore contain newer tritium.

\section{Recovery Percentage}

Mound Laboratory ran experiments on twenty-eight 1/2-in.-diameter RL tubes in 1987. A part of the data is shown in Table 4.3. Statistical analyses on the data from those experiments indicate that approximately $92 \%$ of the tritium would be released at initial fracture of the tube with another $7 \%$ being released from the glass and phosphor surfaces when elevated to $500^{\circ} \mathrm{C}$. For the following computations, $90 \%$ initial recovery was used for the lowCurie signs and $95 \%$ initial recovery rate was used for the higher curie level 
devices. This scenario was justified on the basis that the retention is a surface area phenomenon and the surface area-to-volume ratio is lower in the case of the larger tubes. For example, the Mound data on the fracture and measurement of twenty-eight 1/2-in.-diameter by 10-in.-1ong tubes (50-Ci development airfield tubes) indicate $8 \pm 2$ percent of the tritium $(0.02$ $\mathrm{Ci} / \mathrm{cm}^{2}$ ) was left on the surface after fracture (Table 4.3). Another tube study of $1-\mathrm{Ci}$ instrument lights used as range indicator back 1ights and $8-\mathrm{C} i$ aiming post lights by the U.S. Army indicated a similar result of $0.02 \mathrm{Ci} / \mathrm{cm}^{2}$, but with different surface-to-volume ratios and fill pressures, the tritium on the wall was about $14 \%$ and $4 \%$, respectively.

\section{Labor Cost}

A typical DOE contractor burden rate of $350 \%$ has been applied to the labor portion (rate of $\$ 28.00$ per manhour) of the cost analysis for each type $\mathrm{RL}$ device destined for recycle.

\section{Tritium Value}

A tritium value of $\$ 3.00$ per $C i$ was established for this comparison.

\section{Residual Tritium}

Experimental data show that less than $10 \%$ of the tritium within a glass tube remains on the surfaces of the glass shards following fracturing and collection of the gases. Shards from a $20-\mathrm{Ci}$ sign would contain at most $10 \%$ of the remaining $10 \mathrm{Ci}$ of tritium at EOL. If the tritium in the shards is not to be recovered, several batches of shards are consolidated into a package that has less than $1000 \mathrm{Ci}$ of total tritium per package. If the tritium in the shards is to be recovered (Table 4.6), it is assumed that $5 \%$ of the original tritium ( $10 \%$ of the $50 \%$ remaining at EOL) can be reclaimed. Thus, $1.0 \mathrm{Ci}$, worth $\$ 3.00$, can be reclaimed from the shards from each $20-\mathrm{Ci}$ sign. For signs with 166-Ci tubes, the shard trash is assumed to contain $-6 \mathrm{Ci}$ per tube.

Waste streams from the process for recovering tritium for exit signs include the plastic case with low specific activity containment on the pieces from some small degree of breakage during disassembly. This is the case with or without recovery of residual tritium. The waste streams from ORNL 1 ight 
wands are similar. Waste streams from the process for recovering tritium from USAF 6-tube panels (Table 4.7) include the metal frame and plastic front with low specific activity surface contamination.

\section{Discard Limit}

The discard limit for tritium in residual trash was computed to be less than $25 \mathrm{Ci}$ or $0.002 \mathrm{~g} \mathrm{~T} / 100 \mathrm{~g}$ of trash and compares to an accepted value of $0.008 \mathrm{~g} \mathrm{~T} / 100 \mathrm{~g}$ of trash as the discard limit in Mound's tritium recovery operation. This difference is due to the high purity of the recovered gas and to the relatively high density of the waste stream, i.e., borosilicate glass shards.

\section{Results}

This assessment indicates that value of the tritium recovered from $20-\mathrm{C} i$ exit signs (Table 4.5) and the residuals of other small devices (Table 4.6 ) is less than the processing cost. For larger devices (Tables 4.6 and 4.7 ), the value of the recovered tritium is greater than the processing cost.

\subsection{CAPITAL COSTS}

Facilities for tritium processing are very costly because of the need for glovebox secondary containment of the process and effluent capture. Additionally the need for isotopic enrichment requires multi-million dollar enrichment facilities to be available. The value of the tritium to be processed from the ORNL labs is less than $\$ 1 M$, so it is not practical to build a facility to reclaim tritium. Rather it makes economic sense to adapt facilities at an existing DOE tritium facility. These facilities are Mound, Savannah River Site, and the Los Alamos Tritium Systems Test Assembly.

Facilities for the disassembly, packaging for calorimetry, gas release and waste packaging require a glovebox approximately $8 \mathrm{ft}$ long. The capital cost for the glovebox and support facilities and installation is estimated at \$150K. The gas release apparatus with its ram and vacuum chamber is estimated to be $\$ 50 K$ installed. The gas processing equipment is presumed to be available at the existing tritium facilities with connection costs of \$50K. This 
implies a glovebox and gas recovery addition and connection to an existing system would be $\$ 250 \mathrm{~K}$ and incorporation of a gas recovery system into an existing glovebox is about $\$ 100 \mathrm{~K}$.

\subsection{COMPARISON OF TRITIUM RECOVERY COSTS WITH DIREOT DISPOSAL COSTS}

The cost of processing EXIT signs for tritium recovery is compared with the value of the recovered tritium on a dollars-per-EXIT sign basis in Table 4.5. The comparison shows that recovery processing cost (\$89.88) was significantly more than the value of the tritium that could be recovered $(\$ 27.00)$; thus, tritium recovery based on this comparison alone appears uneconomical. Since recovery of tritium from EXIT signs is now limited to the operation in England, most EXIT signs sold in the United States are currently disposed by burial at the end of their useful lives. Thus, a further cost comparison between reprocessing and disposal of the EXIT signs was needed in light of the reported cost effectiveness of the English process. This section, therefore, makes this comparison.

In this comparison the value of the recovered tritium was taken as a credit for the reprocessing process; no disassembly of the EXIT signs at a radioactive waste disposal site was assumed. The number of signs that could be disposed of in a 60-gal high-integrity container (HIC) at the Barnwell disposal site was roughly estimated for determination of a base case disposal cost estimate. The number of signs that could be disposed of in a HIC was then varied up and down by about a third for determination of the cost sensitivity.

Shipping costs for the exit signs to either a recovery site or a disposal site are excluded from this comparison because shipping would occur in either case. Only costs at the disposal site are developed for the comparison.

Following are the cost rates effective July 1, 1991, for disposal of radioactive wastes containing tritium at the Barnwe11, South Carolina, waste disposal site. These were obtained from the site operator, Chem-Nuclear Systems, Inc., by telephone or from their rate schedule. 


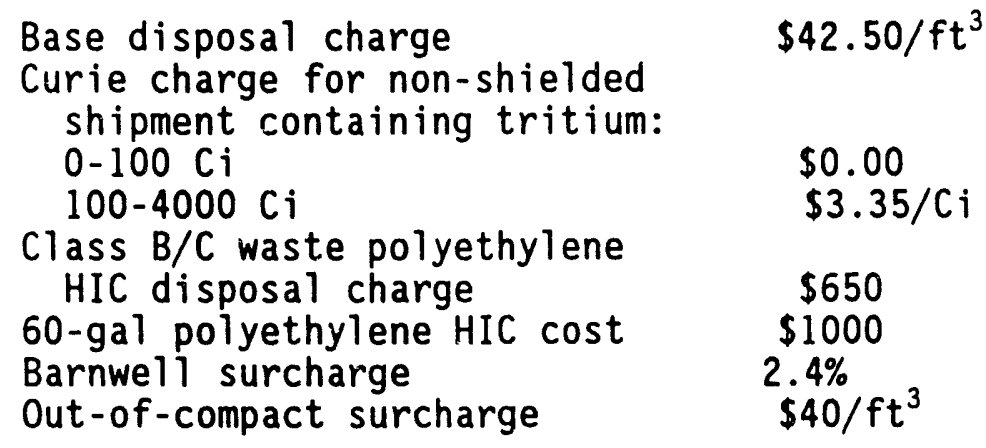

For a cost comparison, it is assumed that a 60-gal HIC is used for disposal of EXIT signs, and that the signs to be disposed have $10 \mathrm{Ci}$ each and have dimensions of $9.75 \times 13.75 \times 1.25$ in., a standard size made by one manufacturer. Although the maximum number of Curies that can be placed into a container is 1000 without requiring an expensive, highway controlled shipment, the 60-gallon HIC would probably not hold the number of signs needed to total $1000 \mathrm{Ci}$. Although not necessarily optimal, one arrangement of EXIT signs allowed for placement of approximately 74 signs. In this arrangement for purposes of estimation, 27 signs could be placed flat, 39 placed on edge with the long dimension horizontal, and $8 \mathrm{placed}$ on edge with the long dimension oriented vertically. At $10 \mathrm{Ci} / \mathrm{sign}$ the $\mathrm{HIC}$ would hold $740 \mathrm{Ci}$.

Using $740 \mathrm{Ci}$ as the disposal quantity, the 60-gal HIC having a disposal volume of $10.2 \mathrm{ft}^{3}$ as the container, and the Barnwell rate schedule, the costs given in Table 4.9 were calculated.

This total cost gives the following unit costs for disposal of the exit signs:

$\begin{array}{ll}\text { Cost per sign for } 74 \text { signs } & =\$ 63.69 \\ \text { Cost per } \mathrm{ft}^{3} \text { for the } 10.2 \mathrm{ft}^{3} \text { HIC } & =\$ 462.05 \\ \text { Cost per } \mathrm{C} i \text { for } 740 \mathrm{C} i & =\$ 6.37\end{array}$ 
TABLE 4.9. Disposal cost for 74 RL EXIT Signs

\begin{tabular}{|c|c|}
\hline $\begin{array}{l}\text { Base disposal } \mathrm{Ci} \text { charge }\left(10.2 \mathrm{ft}^{3} \times \$ 42 / 5-/ \mathrm{ft}^{3}\right) \\
\text { Curie charge } \\
\text { ( } 740 \mathrm{Ci}-100 \mathrm{Ci}=640 \mathrm{Ci}) \text { e } \$ 3.35 / \mathrm{Ci} \\
\text { Class } \mathrm{B} / \mathrm{C} \text { waste (Polyethylene } \mathrm{HIC}) \\
\text { Polyethylene HIC purchase cost } \\
\text { SUBTOTAL }\end{array}$ & $\begin{array}{lr}= & \$ 433.50 \\
= & \$ 0.00 \\
= & \$ 2144.00 \\
= & \$ 650.00 \\
= & \$ 1000.00 \\
= & \$ 4227.50\end{array}$ \\
\hline $\begin{array}{l}\text { Barnwe il surcharge e2.4\% } \\
\text { (excludes HIC cost) } 0.024 \times \$ 3227.50 \\
\text { SUBTOTAL }\end{array}$ & $\begin{array}{l}=\$ 77.46 \\
=\$ 4304.96\end{array}$ \\
\hline $\begin{array}{l}\text { Out-of-compact surcharge; } 10.2 \mathrm{ft}^{3} \times \$ 40 / \mathrm{ft}^{3} \\
\text { TOTAL }\end{array}$ & $\begin{array}{l}=\$ 408.00 \\
=\$ 4712.96\end{array}$ \\
\hline $\begin{array}{l}\text { Unit cost per } \\
\text { Cost per } C i f\end{array}$ & $\begin{array}{r}\$ 63.69 \\
\$ 462.05\end{array}$ \\
\hline
\end{tabular}

For practical purposes the cost per sign for disposal, $\$ 63.69$ and the net cost per sign for tritium recovery and sale, $\$ 62.88$ (\$89.88-\$2700), are virtually the same.

If the EXIT signs were of such dimensions that size had no impact and that $999 \mathrm{Ci}, 99$ signs having slightly more than $10 \mathrm{Ci}$ each, could be placed into a HIC, the only changes in disposal surcharges would be the $\mathrm{Ci}$ surcharge and the Barnwell surcharge. The $C i$ surcharge would increase to $\$ 3011.65$ and the Barnwell surcharge to $\$ 98.28$ to give a total disposal charge of $\$ 5601.43$ for a 60-gal HIC. The resulting unit cost for 99 signs would be about $\$ 56.58$, nearly $11 \%$ less than the base disposal cost of $\$ 63.69$. The cost per C $i$ would a) so decrease to about $\$ 5.60$, but the cost per $\mathrm{ft}^{3}$ would increase to about $\$ 549$ because the total disposal cost would increase while the disposal volume would remain the same.

If the exit sign dimensions or other factors restricted the number of signs that could be placed into the 60-gal HIC to 50 signs containing $500 \mathrm{Ci}$, the disposal cost per sign would increase. The changes in disposal surcharges would again be only the $\mathrm{Ci}$ surcharge and the Barnwell surcharge, and these would change, respectively, to $\$ 1340$ and $\$ 58.16$ to give a total disposal cost 
of $\$ 3889.66$ for the 60 -gal HIC. The unit disposal costs would change to $\$ 77.79$ per sign (about $22 \%$ more than the base disposal cost), $\$ 7.88$ per $\mathbf{C i}$, and $\$ 384$ per $\mathrm{ft}^{3}$.

It is concluded from the comparison of the costs of the base case of direct disposal of 74 exit signs with those for the conceptual tritium recovery process that there would be an insufficient economic advantage acquired by reprocessing. Reprocessing appears at best to have break-even or indifferent economics, i.e., it is not cost effective. If 99 signs could be disposed of directly in a HIC, the comparison further indicates that repracessing would have a negative economic effect. However, with a maximum of 50 exit signs disposed of in a HIC, the conceptualized tritium recovery process would be cost effective because the $\$ 62.88$ cost per sign for recovery is less than the $\$ 77.79$ per sign for disposal.

If tritium were to increase in price from $\$ 3.00$ to $\$ 4.00$ per Ci with no process operating cost change, the cost for tritium recovery and sale would decrease to $\$ 53.88$ per sign from the $\$ 62.88$ estimated net cost and make the process cost effective. An even higher price for tritium would be needed if capital recovery for new facilities was required. 


\subsection{CONCLUSIONS}

The following conclusions are made for this study:

- Tritium in any kind of RL device at EOL can be recovered by fracture and bakeout methods. The decision to recover devices can be based on minimization of tritium going to a burial ground or based on the economic value of the recovered tritium. It is economically advantageous to recover the tritium in the ORNL development tubes, runway lights, and wands by fracture and optional bakeoff of the shards. The cost of disassembly of EXIT signs makes the cost of recovery (\$62.88 per sign) more than the value of the tritium. If the desired environmental goal is minimization of tritium in tritiated waste, the additional cost could be added to the purchase price of an EXIT sign by the vendor to cover future recovery costs.

- A DOE sponsored recovery facility for EOL RL devices should be located at an existing DOE tritium facility that has tritium enrichment facilities. This takes advantage of the large capital investment made at these sites to handle tritium safely and produce an enriched tritium product for resale to the RL device manufacturers.

- Tritium sales by ORNL to commercial customers totaled 14.4 million $\mathrm{Ci}$ from 1980 through 1989 for an average for the 10 years of 1.44 million annually. A survey of U.S. manufacturers of RL devices revealed that the total amount of tritium placed annually in RL devices sold was roughly 1.3 million $\mathrm{Ci}$ when averaged over 5 years, a near agreement between ORNL tritium sales and tritium in RL devices produced. The primary type of RL device sold in number and in $\mathrm{C} i$ is self-luminous EXIT and other emergency signs. Production is expected to increase about 8 to $10 \%$ per year.

By far the larger portion of the RL lighting devices produced are used in general public facilities. Compared with the civilian sector, the military is not a major user of the RL devices. Since 1977 the U.S. Army acquired about 109,000 devices having about $408,000 \mathrm{Ci}$ of tritium; a large majority of these were exit signs having up to $10 \mathrm{Ci}$ of tritium. The U.S. Air Force has disposed of devices, mostly EXIT signs, having a total amount of tritium of less than $10,000 \mathrm{Ci}$, which indicates little usage of RL devices. The U.S. Navy does not have a large number of RL light sources, and those that they do possess do not require special licensing or registration.

PNL, since 1982, has had under its control over 1000, 1arge prototypic RL lights made at ORNL or made commercially for remote airfield runway applications. The undecayed tritium content is $487,551 \mathrm{Ci}$; decayed, $364,912 \mathrm{Ci}$. 
- At the end of the service lives, RL lights are disposed by land burial at one of three sites: the Barnwell waste disposal site in South Carolina, the Richland disposal site in Washington, or the Beatty disposal site in Nevada. Shipment of waste to these sites must conform to 49 CFR 173 and to 10 CFR 71. If a Type A shipping package were to be used, the tritium content of the package must be less than $1000 \mathrm{Ci}$; if the amount were greater a Type B package would be required and special requirements such as restricted vehicle movements would have to be met, all of which combine to make a costly procedure.

Disposal must conform to requirements of agreement states or to 10 CFR 61. If tritium in the waste package were to exceed $40 \mathrm{Ci} / \mathrm{m}^{3}$, the waste falls into Class $B$, and the Class $B$ package must maintain its structural stability for 300 years. High integrity containers (HICs) are used to provide the structural stability. The Barnwell site uses polyethylene HICs which are further placed into concrete overpacks in a relatively shallow but stable trench for $C l a s s B$ and $C$ wastes; this is due to the high water table at the site. At the other sites Class $B$ and $C$ wastes in stainless steel HICs are placed $15 \mathrm{~m}$ below ground level.

- As an alternative to disposal, EXIT signs and airfield runway signs can be processed for recovery of their tritium contents. One firm has a facility in England that reports use of a marginally cost-effective, proprietary process for recovery of tritium.

- Another process has been conceptualized at Mound Laboratory for this report. The conceptual process is not cost effective if the value of the tritium recovered is compared with the operating costs for the process facility. The processing cost is $\$ 89.88$ per exit sign containing $10 \mathrm{Ci}$ at the end of service 1 ife $(20 \mathrm{Ci}$ at start of use) compared with the $\$ 27$ at $\$ 3 / \mathrm{C}$ for the recoverable $9 \mathrm{Ci}$. This would give a net cost of $\$ 62.88$ per exit sign for the processing. Even with saving the costs for disposal, processing appears only to about break even economically; the estimated disposal cost at the Barnwell site for 74 signs containing $740 \mathrm{Ci}$ would be $\$ 63.69$ per sign. This is based on using a 60-gal, polyethylene HIC having a disposal volume of $10.2 \mathrm{ft}^{3}$ and assuming the waste source was out of the South Carolina compact. The number of signs, not necessarily optimal, was estimated using dimensions of a typical EXIT sign and HIC dimensions. However, a sensitivity evaluation showed that if only about 50 signs $(500 \mathrm{C} i)$ could be placed into a HIC and disposed, the conceptualized recovery process would be cost effective; the disposal cost per EXIT sign would be $\$ 77.79$ as compared with $\$ 62.88$ for reprocessing.

- If tritium were to increase in value to $\$ 4.00 / \mathrm{Ci}$ without changes in reprocessing costs, the net cost of tritium recovery would decrease to $\$ 53.88$ per sign; reprocessing would then be cost effective when compared with $\$ 63.69 /$ per sign for disposal. 


\subsection{REFERENCES}

10 CFR 30-35. 1988. U.S. Nuclear Regulatory Commission, U.S. Code of Federal Regulations.

10 CFR 61. 1988. U.S. Nuclear Regulatory Commission, U.S. Code of Federal Regulations.

10 CFR 71. 1988. U.S. Nuclear Regulatory Commission, U.S. Code of Federal Regulations.

49 CFR 173. 1988. U.S. Department of Transportation, U.S. Code of Federal Regulations.

Tompkins, J. A., K. W. Haff, and F. J. Schultz. 1990. Radioluminescent (RL) Lighting System Program-Annual Report: October 1, 1986-September 30, 1987, ORNL/TM-11503, Oak Ridge National Laboratory, Oak Ridge, Tennessee. 


\section{DISTRIBUTION}

No. of

Copies

OFFSITE

12 DOE/Office of Scientific and Technical information

3 J. A. Coleman, Deputy Director Office of Waste Operatiors EM-32

Department of Energy

Washington, DC 20545

R. B. Chitwood

Office of Isotope Production \& Distribution Programs

Department of Energy

Washington, DC 20545

J. A. Tompkins

SAIC

2109 Airpark SE

Albuquerque NM 87106

14 R. E. Ellefson

EG\&G Mound Applied Technologies

P. 0. Box 300

Miamisburg $\mathrm{OH}$ 45343-0897
No. of

Copies

ONSITE

2 DOE Field Office, Richland

R. B. Goranson (2) (A5-90)

48 Pacific Northwest Laboratory

C. R. Allen (P7-43)

R. F. Hazelton (3) (P8-10)

L. K. Holton (P7-43)

J. H. Jarrett $(P 7-43)$

G. A. Jensen (35) (G6-01)

J. L. McEl roy (P7-46)

Publishing Coordination

Technical Report Files (5) 

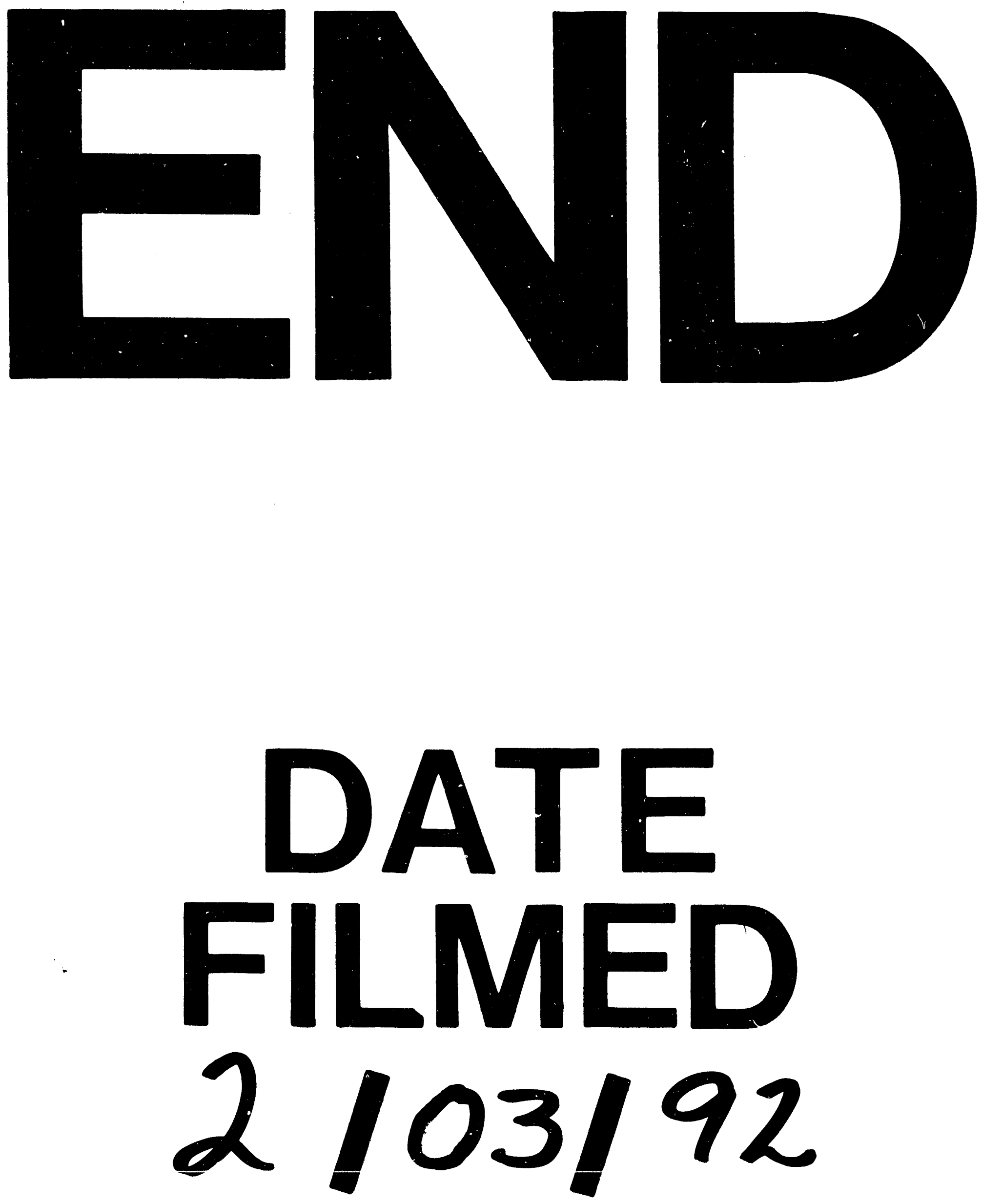